\title{
Los museos de frontera de la provincia de Buenos Aires: entre el gliptodonte y el indio poblador
}

\author{
por \\ Mónica Quijada ${ }^{1}$ \\ Instituto de Historia, CCHS-CSIC \\ Madrid
}

A lo largo del siglo XIX la provincia argentina de Buenos Aires fue un espacio fronterizo en el que la sociedad mayoritaria, en oleadas, fue extendiéndose de norte a sur, empujando a las poblaciones indígenas de la zona y creando al compás de su avance nuevas poblaciones y ciudades. Una parte de los grupos indigenas quedaron dentro del lado "blanco» de la frontera, que era un espacio poroso, en el que se dieron múltiples interacciones y mestizajes. A lo largo del siglo XX en las antiguas ciudades de frontera se crearon museos destinados a guardar la memoria de la comunidad, que son en parte la contrapartida, en América, de los museos «coloniales» europeos. El objetivo del presente artículo es estudiar la relación de esos museos con los distintos contingentes de población que fueron ocupando las tierras, en particular las agrupaciones de «indios amigos» que se fueron integrando en la frontera al compás del avance poblacional. Los museos estudiados, mayoritariamente comunitarios, se han clasificado a partir de cuatro categorias: museos pot pourri, «culturalistas», «estetizantes»e «historizantes》.

PALABRAS ClAVE: museos; frontera; ciudades de frontera; memoria; comunidad; indios amigos; indio poblador.

1 El presente artículo se inscribe en el proyecto de investigación HAR2009-10107. Gracias al apoyo del proyecto pude realizar un fructífero viaje de investigación a distintas localidades de la provincia de Buenos Aires. Quiero agradecer especialmente la amabilidad y extraordinaria profesionalidad de los directivos y encargados de las instituciones aquí reseñadas, en particular el Prof. Roberto Castro, Director General de Turismo, Museo y Archivo Histórico «Julio de Vedia» de la Municipalidad de 9 de Julio, El lic. Gabriel A. Eilers, Director del Museo Etnográfico y Archivo Histórico «Enrique Squirru» de la ciudad de Azul, la Lic. Sandra G. Adam, Encargada del Archivo, y la museógrafa Juliana Aguirre, de la misma institución; así como la Encargada del Museo Casa de Cultura de Tapalqué. Un agradecimiento especial debe dirigirse a «Miguelito el Melenudo», del Museo Dámaso Arce de Olavarría, que nos hizo fácil un recorrido inicialmente difícil — casi imposible — debido a la escasez de personal de dicha 
La consciencia de que la memoria de un grupo está integrada tanto por recuerdos como por olvidos forma parte del patrimonio conceptual desde que Ernest Renan formulara su conocido discurso sobre la nación ${ }^{2}$. Recuerdos y olvidos constituyen elementos inescindibles de la identidad colectiva y no son casuales, ni tampoco neutros. Menos aún, cuando además de afectar a partes del pasado común, involucran a sectores poblacionales que objetivamente conviven dentro de la comunidad.

Este problema está en la raíz de la mayor parte de los museos a los que nos vamos a referir. Difíciles de clasificar por sus contenidos, así como por la voluntad y el discurso de su exhibición, lo que los une es su condición de «museos de frontera». Este último vocablo debe entenderse no como una línea trazada en un mapa que divide espacios administrativamente delimitados, sino en el sentido que adquirió en el siglo XIX en algunos países americanos que durante décadas fueron expandiéndose sobre espacios considerados como parte del territorio nacional, pero que estaban ocupados por poblaciones no reconocidas como propias, y por tanto no formaban parte del cuerpo político. Ámbito poroso, pleno de interacciones, mestizajes e intercambios ${ }^{3}$, se define sin embargo como frontera por su vinculación a actos colectivos de violencia por parte de dos culturas que luchaban por el mantenimiento, unos, y la ocupación, otros, de unas tierras que ambos consideraban propias.

A lo largo del siglo XIX, la provincia argentina de Buenos Aires fue por definición un espacio fronterizo. La sociedad mayoritaria, en oleadas y a lo largo de muchas décadas, fue extendiéndose de norte a sur por el territorio provincial, creando al compás del avance poblaciones que se asumieron a sí mismas como «de frontera». En 1879 finalizó la ocupación del territorio provincial, y en 1885 el gobierno nacional dio por terminada la última guerra con el indio denominada — no casualmente - «Conquista del Desierto», la segunda conquista. Se trató por tanto de una acción interna de ocupación territorial y

institución. Por supuesto, nada de esto hubiera sido igual sin el apoyo y la compañía de Federico W. Mauriño, «el baqueano Fede». Finalmente, en estos agradecimientos estaba incluido el Padre Meinrado Hux, fundador del «Museo del Indio» de Los Toldos. Tristemente, cuando estaba acabando este artículo me enteré de su fallecimiento. El trabajo va dedicado a él, a su labor incansable y a su memoria.

2 Renan, 1987.

3 Sobre la condición porosa e interactuante de la frontera con el indio es útil el concepto de middle ground acuñado por Richard White, 1991. 


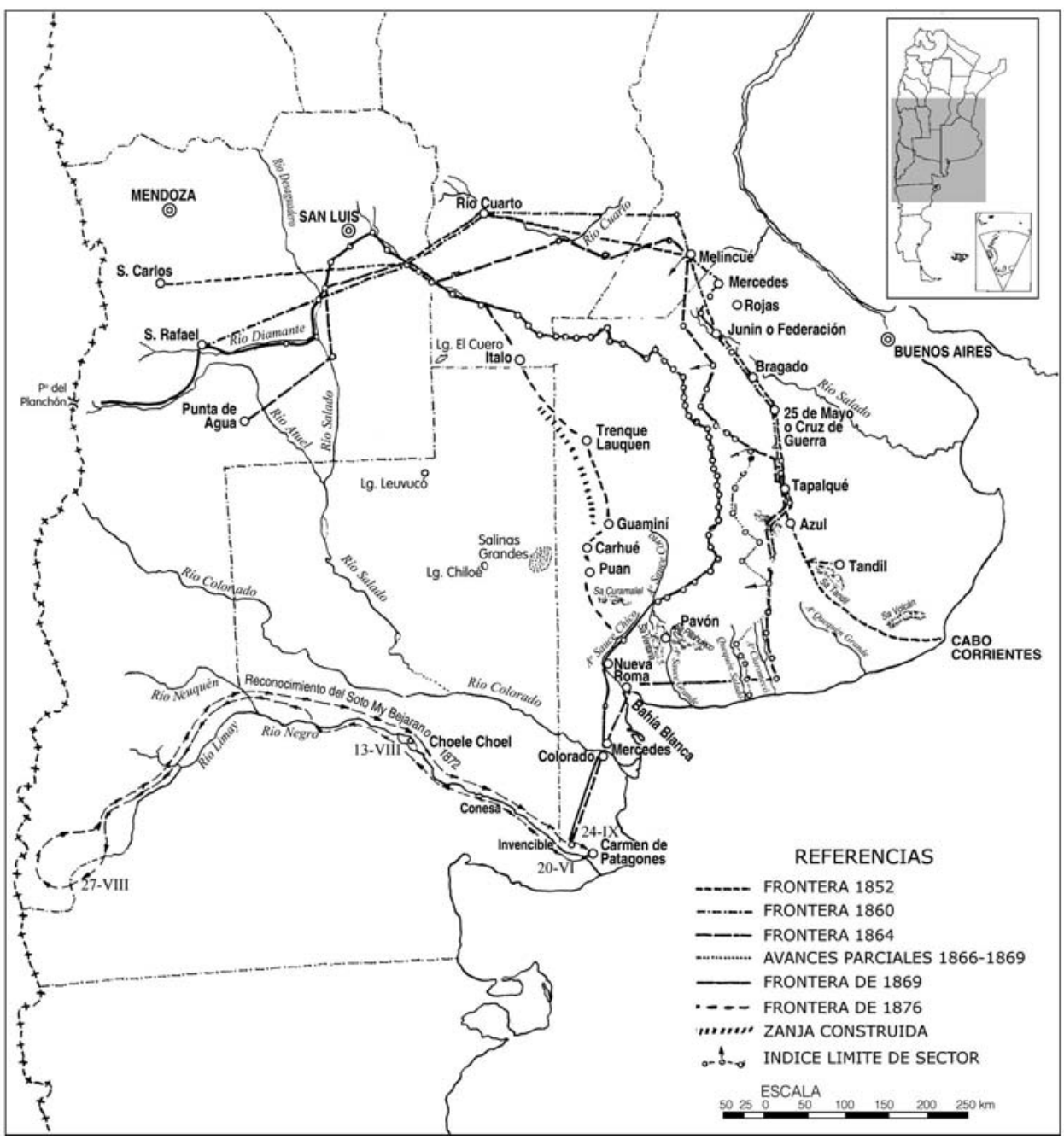

MAPA. Avance de la frontera en la provincia de Buenos Aires, entre principios del siglo XIX y 1879. Fuente: Ingrid de Jong, en Mónica Quijada (ed.), De los cacicazgos a la ciudadanía.

Sistemas politicos en la frontera, Río de la Plata, siglos XVIII-XX, Berlín, 2011: 105.

poblacional que formó parte de la construcción de la nación y del estado. Pero implicó también una voluntad de colonización sobre unas tierras desconocidas y unos grupos humanos considerados ajenos.

Lo cierto es que tanto la ocupación de las tierras como la idea de sujeción de poblaciones ajenas tienen en común una sorprendente identidad de imagi- 
narios con la experiencia de los grandes imperios coloniales europeos: en el siglo XIX compartieron el orgullo de la imposición del hombre civilizado sobre el hombre primitivo desde la perspectiva darwinista del triunfo de los más aptos. Desde finales del XX, con el avance del multiculturalismo, ha surgido en ambos casos el cruce de aprensión y culpa que lleva a tratar de marginar las otrora glorias de la colonización. En el siglo XIX, ambas formas de expansión se vincularon al pensamiento científico, que a su vez unió el interés por los grupos humanos y su estratificación «racial» a los principios de colección y exhibición. En el siglo XXI, la valorización de la diversidad humana ha generado problematizaciones colaterales que afectan de forma específica a las prácticas expositivas de materiales antropológicos y etnográficos.

Por todo lo anterior - que se completa en ambos casos, en el siglo XIX, con la consolidación de los Estados nacionales como telón de fondo- consideramos que la primera clasificación que reúne a estos museos de frontera es la de ser «coloniales», ya que encuentran puntos de equivalencia «hacia adentro», con lo que los grandes museos europeos tienen de colonial «hacia afuera». Sin embargo, junto a estas semejanzas hay también diferencias no desdeñables. Sobre todo, el hecho de que los museos coloniales europeos son fruto de una actuación que llevó a los países de origen a ocupar tierras muy alejadas de sus respectivos territorios nacionales. Por ello no hubo en este caso las «fronteras porosas» a las que nos hemos referido antes. La línea de demarcación entre el «otro» y el «nosotros» ${ }^{4}$ fue profunda e inequívoca; de hecho, hubo de esperarse hasta ya avanzado el siglo XX para que una parte de las poblaciones conquistadas se incorporara a la ciudadanía de sus respectivos estados coloniales como consecuencia de movimientos migratorios que por razones distintas, aunque mayoritariamente económicas, les condujeron a tierras europeas.

Muy otra es la situación de nuestras poblaciones de frontera en la Argentina decimonónica. La condición contigua, plástica y flexible de esos espacios dio lugar a trasvases de población entre uno y otro lado de la llamada frontera. Incluso en los actos de violencia que configuraron la demarcación entre dos ámbitos culturales hubo cruces significativos de prácticas y mestizajes. En el lado de la sociedad mayoritaria, extensos contingentes de indios amigos formaron parte de las milicias, con grados militares. Hubo tribus que recibieron tierras en propiedad y fueron vecinos de las poblaciones de frontera. Grupos indígenas intervinieron en la mayoría de las contiendas civiles de la sociedad blanca, apoyando a unos bandos o a otros; es decir, formaron parte de la cons-

4 Véase el artículo de Jesús Bustamante en este mismo volumen. 
trucción nacional (Mapa). Al finalizar la Conquista del Desierto, en 1885, los indígenas fueron considerados ciudadanos mediante la aplicación del principio del ius soli. Algunos de ellos medraron, tuvieron haciendas, fundaron escuelas, tuvieron hijos en la universidad. Otros - la mayoría - se integraron en niveles sociales más desfavorecidos 5 . De tal forma, a finales del siglo XIX una población en principio ajena habría pasado de la «otredad» inicial a la «mismidad» identificada por la ciudadanía común.

Sin embargo, en la cotidianeidad todo ese proceso fue oscurecido por un gran imaginario que defendió la existencia de dos culturas irredentas que no se habrían cruzado ni mezclado, identificadas por el binomio de «bárbaros y civilizados». La población civilizada habría ocupado todo el territorio nacional, en tanto que la llamada «bárbara» habría desaparecido por la obra de exterminio llevada a cabo por la Conquista del Desierto. Sobre este imaginario, que durante décadas ocultó la realidad evidente de unas fronteras porosas y de una población indígena integrada a la ciudadanía, se ha yuxtapuesto en los últimos años el multiculturalismo. Este último ha introducido un nuevo elemento: el de la culpa que, si bien ha contribuido a la revisibilización del indio, retiene la visión de la pobreza y la explotación como elementos incorporados a la propia identidad indígena y produce miradas y prácticas conflictivas a la hora de tratar a las poblaciones autóctonas. Se trata por ende de imaginarios extraordinariamente extendidos, que comparten los actores del XIX y la propia población actual.

La conversión de los indios en ciudadanos conllevaría que la parte de la memoria que les afecta se hubiera convertido en la memoria del «nosotros» en el mismo momento de la aplicación del ius soli. Pero la invisibilización construida a lo largo de décadas lo impidió. ¿Qué pasa hoy, cuando la revisibiliza-

5 Quijada, 2011. Cfr. especialmente Quijada, parte III, «La lenta configuración de una ciudadanía de frontera». En la provincia de Buenos Aires interesa particularmente señalar la presencia de dos contingentes de indígenas amigos que en 1860-70 (época de fundación de la mayoría de las ciudades que nos ocupan) estaban asentados en la proximidad de las principales poblaciones. Se trata, por un lado, de la tribu borogana bajo las órdenes del cacique Ignacio Coliqueo - que incluye importantes caciques como Melinao, Collinao, o los propios hijos de Ignacio, Justo, Simón, Antonio y Martín Coliqueo-. Su presencia es actualmente fundamental en la localidad de Los Toldos y en las inmediaciones de 9 de Julio y Olavarría. Por otra parte, vinculados a Azul, Tapalqué y Olavarría estaban los indios pampas — de más larga data en el territorio - que en las fechas que nos ocupan se correspondían con una dinastía de caciques llamados Catriel (siendo el más significado entre ellos el llamado Juan Catriel, gran aliado de Juan Manuel de Rosas y más tarde de Bartolomé Mitre). Junto a estos últimos hay que señalar también el grupo indígena de origen tehuelche bajo las órdenes del cacique Maicá, que fue el primer grupo en recibir tierras en propiedad, junto a la localidad de Azul. 
ción vinculada al multiculturalismo ha generado nuevas miradas y prácticas, nuevos compromisos y problemas? Contestar a esta pregunta es el objetivo del presente artículo. Para ello comenzaremos por discutir algunas características globales de los museos de frontera, para luego presentar casos específicos cuyo desarrollo nos llevará a complejizar la clasificación.

\section{Los museos de frontera de la Provincia de Buenos Aires}

En este trabajo no trataremos todos los museos de frontera existentes, ya que sería un ejercicio excesivamente extenso. Por el contrario, hemos seleccionado un conjunto de instituciones de diferentes ciudades que entendemos ofrecen una variedad capaz de ser incorporada en una clasificación.

Se trata en general de museos de poblaciones secundarias, y por lo tanto pequeños, más o menos modestos según los casos, en los que juegan un papel importante la voluntad y la actuación de lo que podríamos llamar las fuerzas vivas del lugar. Aquí no suele ser el Estado el que decide, ni siquiera el alcalde (o intendente, en la terminología argentina). Suelen estar montados a partir de colecciones particulares, pero también contienen objetos difícilmente clasificables que regalan los propios pobladores. Y hay lugares, como nos dijeron en uno de estos museos, en que el pueblo es tan obsequioso con sus recuerdos familiares que dificulta el sentido de la exhibición.

Por eso mismo muchas veces son museos pot pourri, museos «puchero», donde puede encontrarse todo tipo de objetos, desde el vestido de novia de la tatarabuela hasta la foto del último cacique autónomo. Suelen ser museos de memoria comunitaria, en el sentido de la comunidad asentada territorialmente y organizada en instituciones locales que exhibe un interés colectivo por mantener el recuerdo del asentamiento que iniciaron sus bisabuelos. Porque estas ciudades de frontera suelen ser muy recientes, se remontan a 1860 o 1870 , como mucho a 1830 o 40.

Finalmente, la modestia de algunas de estas instituciones no implica que sean miserables o abandonadas. Por el contrario, quienes las organizan suelen ser profesionales que no viven de sus no muy elevados sueldos del museo, si es que los tienen, sino que muchas veces son profesores de la escuela pública o de la propia universidad - historiadores y antropólogos-, gente enormemente entusiasta con lo que hace y de su compromiso con la memoria de su comunidad, en cuyo seno suelen ejercer una pedagogía muy importante dirigida a la población en general y en particular a las escuelas, colegios secundarios e incluso a las universidades cercanas. 
En ese contexto definido por la memoria de la comunidad el tema del indio es importante, porque todos estos museos identifican el momento fundacional de sus respectivos asentamientos con el avance poblacional decimonónico y la guerra con las tribus nativas que campaban por sus respetos en los territorios pampeanos, en una situación inicial de ajenidad con respecto a la sociedad política mayoritaria. Algunas de esas comunidades inscriben incluso su fundación en los momentos finales de la propia Conquista del Desierto. Por tanto, todos estos museos - obra de sus fuerzas vivas a lo largo del siglo XX - son conscientes de participar de un espacio territorial que se caracteriza por haber constituido y expandido la frontera con el indio. Pero esa consciencia se puede expresar de distintas maneras, y es tan elocuente la presencia del indio en el museo, la forma que asume, como el silencio en torno a él; puesto que, como es bien sabido, hay silencios que son clamorosos.

Veremos entonces qué pasa con esos grandes recogedores, plasmadores y creadores de imaginarios que son los museos. Hemos elegido para ese fin instituciones de las ciudades de Azul, Los Toldos, 9 de Julio, Olavarría, Tapalqué y Trenque Lauquen. Son en general museos coloniales, en su sentido básico de ocupación de una geografía y una población inicialmente ajenas; pero son también, la mayoría, museos de comunidad, destinados a mantener y exhibir la memoria de la población allí asentada ${ }^{6}$. Finalmente, presentan algunas diferencias sustanciales que permiten una subclasificación en museos pot pourri, museos culturalistas, museos estetizantes y museos historizantes.

\section{Museos pot pourri}

La población de 9 de Julio fue fundada en 1864 por el general Julio de Vedia en un paraje denominado Cla Lafquen, que en la toponimia mapuche significa «Tres Lagunas». Entre las tropas del general de Vedia figuraba un contingente de indios amigos de la tribu borogana ${ }^{7}$. No es ocioso señalar que la fundación de 9 de Julio se produjo años antes de la Conquista del Desierto (1879-1885), pero en pleno proceso de avance territorial y guerra con el indio.

${ }^{6}$ Para un contraste entre estos museos de comunidad y los que ahora reciben propiamente este nombre, los museos de las comunidades indígenas (los más conocidos son los mexicanos) véase el trabajo de Manuel Burón en este mismo volumen.

7 Los boroganos eran una tribu de origen chileno llegados al lado argentino de la cordillera en la década de 1820. Aliados primero con el gobernador de la provincia de Buenos Aires, Juan Manuel de Rosas, se distanciaron luego de él pasando a revistar entre sus enemigos. A la muerte del gobernador volvieron a crear un vínculo muy fuerte con la provincia, esta vez en la persona del dirigente liberal —enemigo de Rosas_ Bartolomé Mitre. 
Corresponde a unos años que se caracterizaron, en la relación con los indígenas amigos de la provincia, por la entrega de tierras en propiedad llevada a cabo por el presidente Bartolomé Mitre, la profundización de la política de incorporación de estos grupos nativos al ejército - que revistaron tanto en la defensa de las poblaciones frente a los indios hostiles como en las propias guerras civiles dentro de la sociedad mayoritaria- y la expansión, entre ellos, de ideas vinculadas a la construcción nacional, como el patriotismo ${ }^{8}$.

Inmediatamente después de la fundacion de 9 de Julio se procedió a la mensura y amojonamiento del nuevo pueblo y su ejido, de acuerdo con instrucciones del Departamento Topográfico y siguiendo una traza que en su momento se ajustó a los cánones del urbanismo más moderno. Elevada al rango de ciudad en 1911, es hoy un enclave de población poco numerosa (el último censo arrojó una cifra de 45.000 habitantes) pero pujante, dedicada sobre todo a la práctica de la agricultura y la ganadería.

En 9 de Julio se levanta el Museo Julio de Vedia, fundado en 1916. Es una institución municipal, con financiación pública y bastante modesta. Típico museo de comunidad, representa a una población con consciencia de sí misma y del papel señalado que jugó a lo largo del avance fronterizo. Por razones que explicaremos más adelante, es un museo en proceso de cambio en cuanto al edificio que lo contiene, la fijación de prioridades y por tanto la propia exhibición, lo que hay que tener en cuenta a la hora de evaluar sus contenidos y el discurso que los organiza. En su situación actual es dificultoso obtener una visión general porque las salas son muy pequeñas para el abigarramiento de objetos. No hay tampoco lo que hoy llamaríamos un criterio museístico. Pero sí podemos apreciar un criterio evolutivo cuya voluntad de seguimiento lleva a que, allí donde no hay objetos, se suplan con láminas.

El museo se compone de cinco salas con una distribución de objetos que va modificando el discurso. La primera y más grande es la dedicada a la evolución de la tierra y la ocupación del territorio. Tras unas láminas dedicadas al origen de la tierra, se vincula el proceso evolutivo a la aparición del indio arqueológico asociado a elementos de paleozoología. Estos últimos están representados por huesos de gliptodonte y megaterio (animales propios de la fauna paleozoica del lugar) que se presentan vinculados a restos líticos e incluso cerámicos que refieren a los primeros habitantes del territorio. A su vez la presencia humana, en la que la paleoantropología se cruza con la paleozoología, empieza a superponerse en la exhibición con indígenas muy reales e incluso individualmente identificables, que fueron protagonistas - amigos o enemi-

${ }^{8}$ Quijada, 2011. Véase especialmente capítulo 9. 


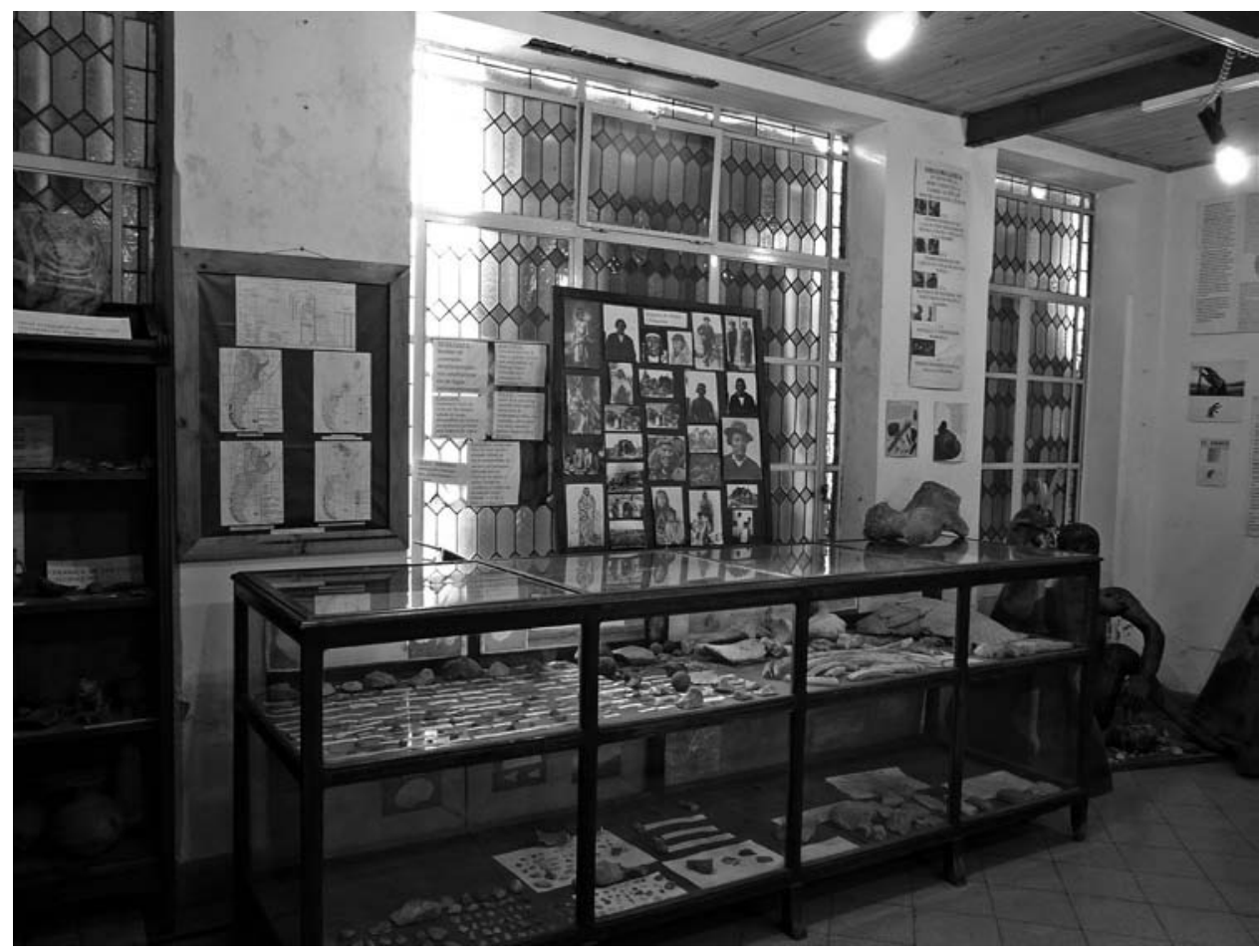

Fото 1. Museo «Julio de Vedia» de la ciudad de 9 de Julio. Restos líticos, fósiles y alfarería. Fotografías de dirigentes indígenas históricos del siglo XIX, mayoritariamente de la Patagonia.

Foto: Jesús Bustamante, agosto de 2011.

gos - de las luchas del siglo XIX. Este cruzamiento es muy común en los museos de frontera.

Con respecto al gliptodonte, el armadillo gigante, hay que decir que es una figura omnipresente en la mayoría de los museos de frontera y suele aparecer asociado al indio prehistórico Como en este caso el museo carece de restos óseos de gliptodonte identificables por su gran caparazón (que sí aparecen en muchos otros museos de este tipo) aquí se exhiben en un cartel, y también en la forma de un pequeño megaterio hecho en molde por los niños de una de las escuelas públicas del lugar, a quienes el museo abre sus puertas como centro educativo.

A continuación el tratamiento evolutivo lleva a un salto en el tiempo, pasándose a la fase histórica del avance de la frontera, la lucha con el indio y el poblamiento de 9 de Julio: armas de fuego, una lanza tacuara (que podía ser utilizada indistintamente por los indios o por las tropas criollas), textiles, el te- 
légrafo - que se introduce precisamente en la última etapa del avance poblacional-, planos de ocupación, así como fotos o dibujos del ejército de línea. Asimismo, varias fotografías de caciques y sus familias se muestran en esta sala. Se trata sin embargo de personajes conocidos de la provincia patagónica de Neuquén (dirigentes de las tribus manzaneras) o de indios tehuelches del lejano sur. No representan a los indios amigos de la localidad. La única referencia a los indígenas de la zona aparece, sin imagen, en un cartel que hace referencia a la batalla de San Carlos, librada contra el cacique huiliche Calfucurá, llegado a las pampas desde Chile en la década de 1830 y que más tarde se convertiría en el gran azote de las poblaciones fronterizas. El texto del cartel menciona a los lanceros de Coliqueo y Catriel - borogano y pampa, respectivamente- indios amigos antes citados que lucharon en el bando de la sociedad mayoritaria. Las imágenes que hacen referencia a los pobladores blancos, por el contrario, se ajustan a la historia de la localidad. Una pared está dedicada a los protagonistas de la campaña al desierto y del poblamiento inicial, entre ellos Julio de Vedia, fundador de 9 de Julio y héroe epónimo del museo.

Nos encontramos, por tanto, con el primer silencio clamoroso que va a jalonar nuestro recorrido: salvo en el cartel antes citado no figuran los indios principales, bien conocidos, que formaron parte de las tropas y la defensa de los fuertes: los Coliqueos, los Catrieles, pobladores ambos grupos de la provincia hasta el día de hoy. La ausencia de fotos de sus caciques y dirigentes principales es clamorosa, porque las hay en el Archivo General de la Nación, son muy conocidas y aparecen en otros museos.

En el centro de la sala, un caballo momificado hace un guiño a la memoria de una comunidad dedicada a las tareas agropecuarias: se trata del equino que le ganó una carrera al ferrocarril cuando este entró por primera vez en 9 de Julio. Con él se abre la voluntad de guardar el recuerdo colectivo de las familias, de los abuelos fundadores, es decir, de la población en tanto comunidad con un pasado común y un presente compartido. Aparecen los antepasados pioneros, sus muebles, sus instrumentos de música, sus máquinas de coser Singer - que nunca faltan- y numerosas porcelanas, así como los vestidos de novia de las tatarabuelas y las casullas ceremoniales de los curas, finamente bordados. La diversidad de elementos de factura europea incluye algunas piezas de calidad que señalan la voluntad de elegancia y «civilización» del nuevo poblamiento.

Las restantes salas dan testimonio de las aspiraciones de progreso de la comunidad, con colecciones de instrumentos de fotografía y medicina (hasta una incubadora) propios de finales del siglo XIX y primeras décadas del XX. Material ciertamente notable que se complementa con fotos antiguas de familias criollas e inmigrantes, asociadas al desarrollo de la población. 


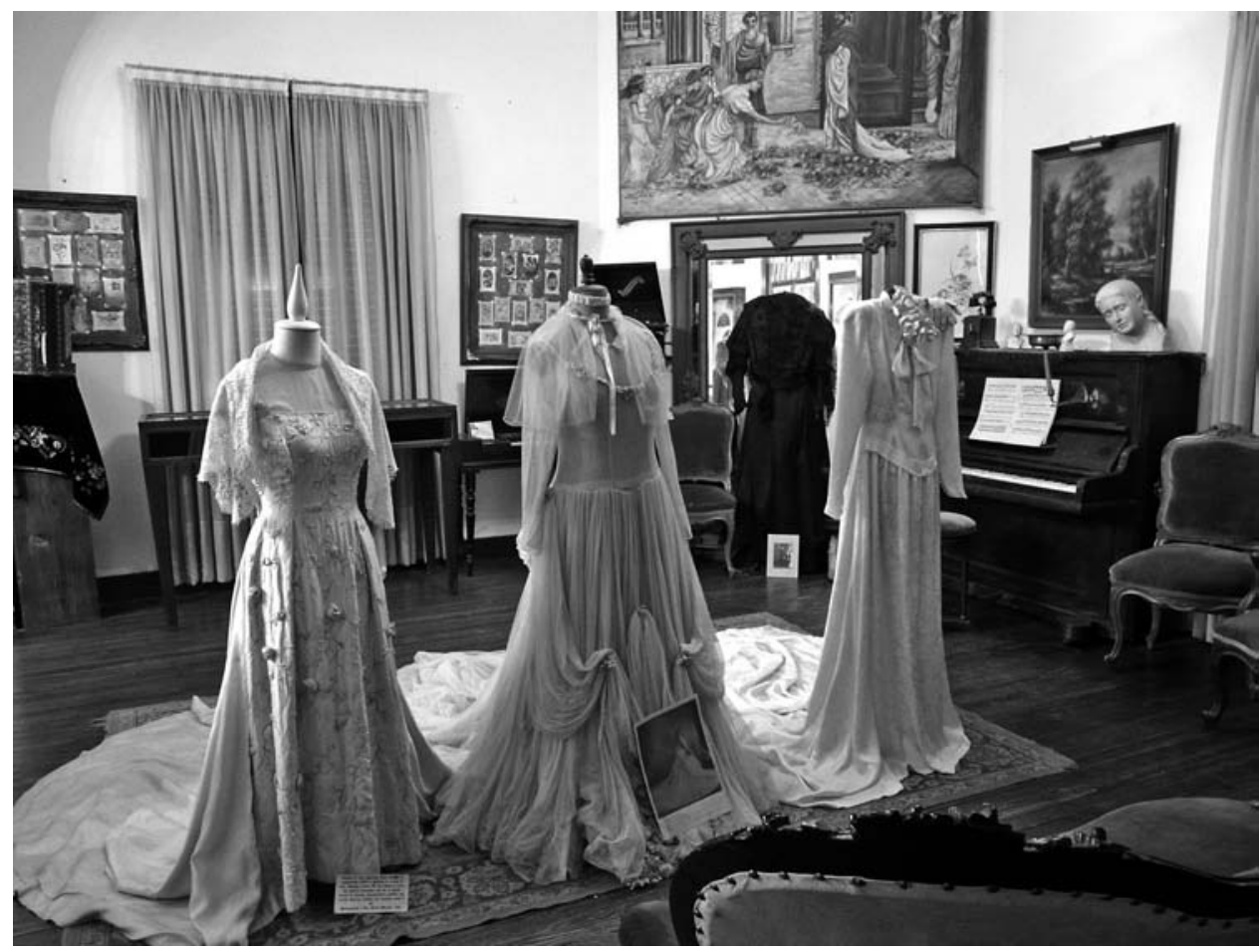

Fото 2. Museo «Julio de Vedia» de la ciudad de 9 de Julio. Objetos cedidos por las familias del municipio. Foto: Jesús Bustamante, agosto de 2011.

Finalmente, las motivaciones artísticas se expresan en un conjunto de cuadros pintados por artistas locales, del siglo XX hasta la actualidad. El origen del conjunto de las colecciones y obsequios, que atestiguan la voluntad de memoria colectiva de la comunidad, proviene de las familias criollas y de ascendencia inmigrante que han donado sus tesoros a lo largo de décadas. Las familias indígenas que pueblan los alrededores de 9 de Julio no están presentes en esta voluntad de memoria.

El museo Julio de Vedia de la ciudad de 9 de Julio era una institución como tantas de su tipo, hasta que en el año 2006 una cuestión fortuita de la naturaleza - un periodo prolongado de sequía seguido de grandes inundacioneshizo que empezaran a aflorar restos líticos y óseos. Aunque este tipo de restos ha sido tradicionalmente trasladado al importante Museo de La Plata para su estudio y conservación, en este caso se mantuvieron en el sitio y fueron estudiados en asociación con la universidad de la vecina ciudad de Olavarría, a la que está vinculado el actual director del Museo Julio de Vedia. El análisis con 


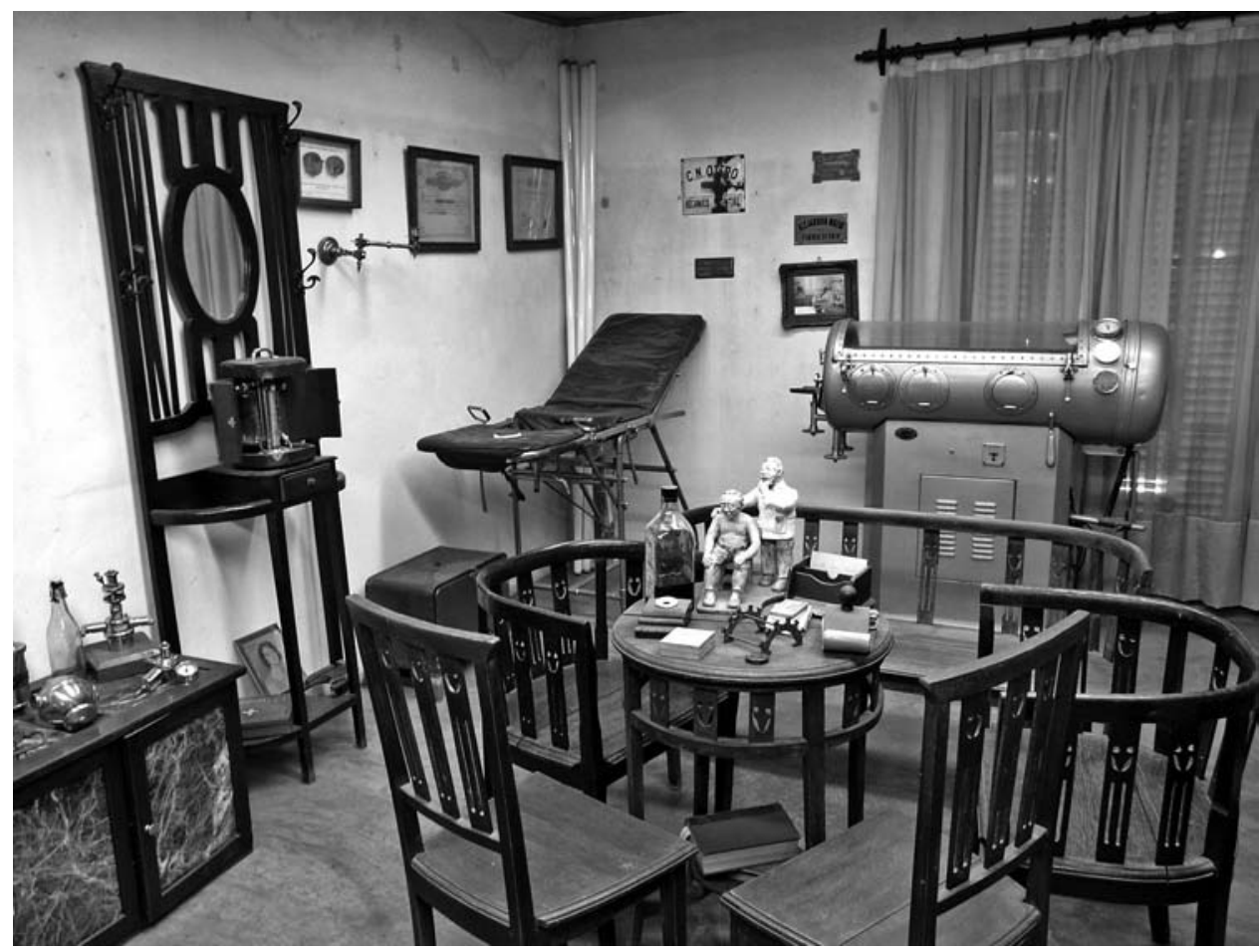

Fото 3. Museo «Julio de Vedia» de la ciudad de 9 de Julio. Instrumentos de medicina utilizados en la localidad entre finales del siglo XIX y primeras décadas del XX (entre ellos, una incubadora). Foto: Jesús Bustamante, agosto de 2011.

carbono 14 dio como resultado que dichos restos se remontaban a más de 10.000 años de antigüedad. Con el tiempo se han identificado seis sitios arquelógicos además de un sitio histórico, el antiguo Fortín General Paza, donde hubo asentamientos de indios boroganos asociados a los elementos militares del fuerte, en la primera mitad del siglo XIX.

Estos descubrimientos inyectaron nueva vida al museo que se ha convertido en centro impulsor de una notable actividad de carácter cultural y científico. Dos actuaciones son particularmente destacables, aunque no las únicas. Por un lado, la implementación del proyecto «El Museo en las Escuelas», que está teniendo un enorme éxito entre la población por la atracción que sienten los niños hacia la paleontología y los indios primitivos. Por otro, la institución está trabajando de forma oficiosa con los arqueólogos de la cercana Universidad de Olavarría, con los que preparan importantes y muy concurridas jornadas periódicas de arqueología. Toda esta actividad ha tenido como consecuen- 
cia una afluencia bastante considerable de objetos arqueológicos -óseos y líticos - al museo, que sobrepasan la capacidad de sus actuales instalaciones. Pero ha servido para que la municipalidad acepte acondicionar para su uso una antigua fábrica eléctrica, a la que están esperando mudarse. Esto implicará sin duda cambios importantes en los criterios de exhibición, que abarcarán tanto el tratamiento de los objetos como el propio discurso expositivo.

El sesgo fuertemente paleontológico que según todos los indicios asumirá el museo Julio de Vedia no modificará, previsiblemente, el silencio clamoroso que implica la ausencia de un personaje, el indio poblador, que después de la conquista del desierto permaneció en el territorio en forma de barrios, sobre todo en las localidades muy cercanas de Bragado, Olavarría, Los Toldos y Tapalqué.

Una de las razones de esta ausencia es histórica: la típica y extendida invisibilización del indígena que se produjo en la Argentina después de la Conquista del Desierto, cuando fueron convertidos en ciudadanos. Pero a esto se le ha sumado una segunda razón, de carácter mucho más reciente: en palabras de uno de los dirigentes del museo, «los pueblos originarios del lugar son recién llegados», es decir, su presencia en el territorio no se remonta más allá del siglo XIX 9 . No obstante, o quizás por eso mismo, su actitud es muy radical en la reclamación de esos restos antiguos como si fueran propios. Actitud que está dificultando la labor del museo, entusiastamente asumida, que implica la conservación, estudio y exhibición de las piezas arqueológicas y paleontológicas.

En resumen - y por el momento - se trata de un museo de comunidad municipal, con voluntad de conservación de memoria colectiva y de pedagogía hacia las nuevas generaciones de esa misma comunidad. Un museo con criterio evolucionista, que reconoce el momento de fundación de la comunidad en el avance de la frontera, y en el que el indio, por lo tanto, no deja de ser el indio enemigo. El indio amigo apenas aparece, y el indio poblador, el indio ciudadano, brilla por su ausencia.

Es además un museo pot pourri, con voluntad exhaustiva, que reúne y expone una gran cantidad de objetos heterogéneos, exhibidos a la manera de estratos que muestran con criterio evolutivo desde el origen de la tierra a la memoria colectiva de la comunidad de origen europeo que se asentó en el territorio. Pero en los últimos años este museo, a raíz de un encuentro fortuito, ha encontrado su vocación: la de museo paleontológico, donde se reúnen el indio arqueológico y el gliptodonte.

9 Esto es particularmente cierto en el caso de la tribu borogana de Ignacio Coliqueo - la más importante en cuanto a poblamiento actual—, llegada a la zona a principios de la década de 1860 . 
El museo Julio de Vedia, de la localidad de 9 de Julio, no es la única institución pot pourri destinada a la memoria colectiva de la comunidad que ha sido tocada por la varita de la voluntad arqueológica. Ejemplo de ello es Tapalqué, con su Museo Centro de Cultura que lleva el nombre de la población.

La ciudad de Tapalqué tiene una historia particularmente llamativa. El primer asentamiento de ese nombre (en realidad Tapalquén, en lengua indígena ${ }^{10}$ ) está actualmente desaparecido. Se levantaba en la margen izquierda del arroyo Tapalquén y las primeras referencias al mismo se remontan a la década de 1830. Se trataba en realidad del aduar principal de la tribu pampa catrielera, aliados incondicionales del gobernador de Buenos Aires y dictador Juan Manuel de Rosas. El asentamiento constaba de numerosos toldos ${ }^{11}$ y algunos ranchos, estos últimos viviendas de miembros de las milicias y de comerciantes que vivían del tráfico con los indios. Este asentamiento, con su respectivo fuerte, es el que más tarde se llamó «Tapalqué Viejo». Cuando la derrota de Rosas abrió camino a un momento de gran confusión entre sus aliados los pampas - ya que Buenos Aires había pasado a manos de los enemigos jurados del dictador-, el cacique Catriel hizo alianza con el temible dirigente huiliche Calfucurá y durante dos años llevó malones ${ }^{12}$ a las estancias de la zona, que antes contribuía a proteger. En 1854 Catriel volvió a las relaciones con Buenos Aires a través de su nuevo hombre fuerte, Bartolomé Mitre, pero para entonces los habitantes no indígenas del lugar — criollos e inmigrantes - habían trasladado el asentamiento a la margen derecha del arroyo Tapalqué. Finalmente, la ciudad de Tapalqué tal como la conocemos hoy fue fundada como tal por decisión del gobierno de Buenos Aires en 186413.

Se trata por tanto de una localidad cuya historia está íntimamente ligada a la presencia indígena, que se mantiene hasta el día de hoy en los alrededores de Tapalqué, aunque al producirse la alianza con Mitre una buena parte de los indios catrieleros se trasladaron a la vecina ciudad de Azul, distante cincuenta kilómetros de aquélla.

El Museo Casa de Cultura de Tapalqué fue fundado en 1942. El enclave actual de la institución no es el más apropiado para conocer los aspectos for-

10 Supuestamente el final «quén» se corresponde con lauquen, laguna en lengua mapugundun (mapuche).

11 Vivienda indígena levantada con palos (de madera o tacuara) y cueros vacunos.

12 Ataques indígenas a las estancias y poblaciones de la frontera.

13 Para una historia de Tapalqué en sus documentos véase la publicación del Museo Roca de Buenos Aires, La historia viva de Tapalqué. Fragmentos de textos documentales para la didáctica de la historia, 1986. Debo agradecer a la encargada del Museo Casa de Cultura de Tapalqué el haberme facilitado este texto inapreciable. 
males y estéticos de la exhibición, pues su edificio tradicional está en proceso de reconstrucción y la colección ha sido trasladada a una suerte de almacén escasamente apropiado para fines museísticos. No obstante, los objetos exhibidos hablan por sí mismos a la hora de definir el criterio y discurso de la exhibición. Sus fundamentos no son distintos a los de un museo pot pourri tal como lo hemos presentado con más prolijidad en el caso de 9 de Julio: elementos paleozoicos y paleoantropológicos asociados (en este caso cuentan con un auténtico caparazón de gliptodonte); objetos que rememoran el avance poblacional y la Conquista del Desierto y finalmente una gran cantidad de piezas cedidas por miembros de la comunidad y que representan la voluntad de guardar la memoria de los antepasados fundadores.

En el caso de Tapalqué dos características son destacables: la exhibición de una magnífica colección de armas, desde las usadas en las guerras de Indepen-

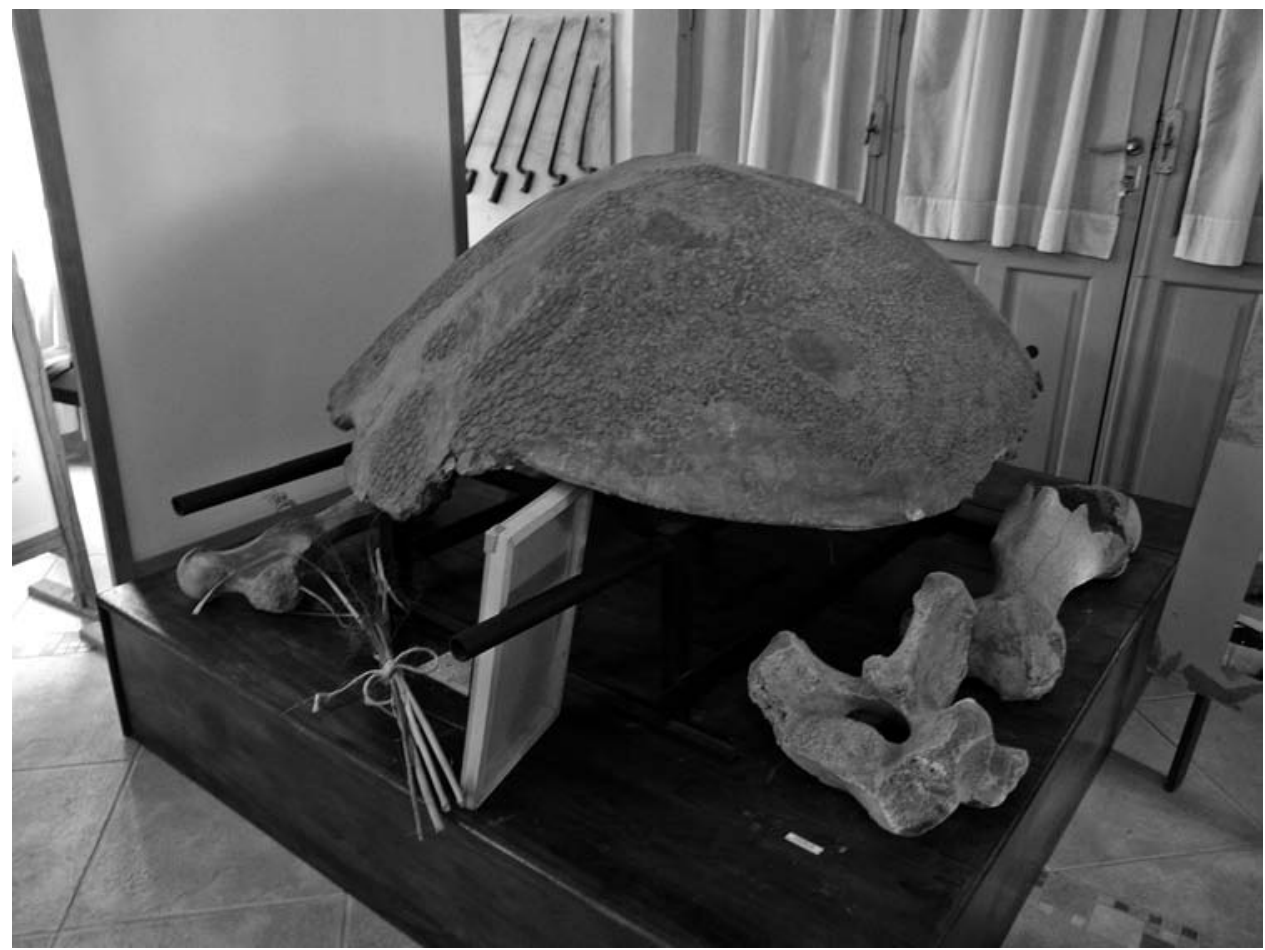

Fото 4. Museo Casa de Cultura de Tapalqué. Caparazón de gliptodonte. Foto: Jesús Bustamante, agosto de 2011. 


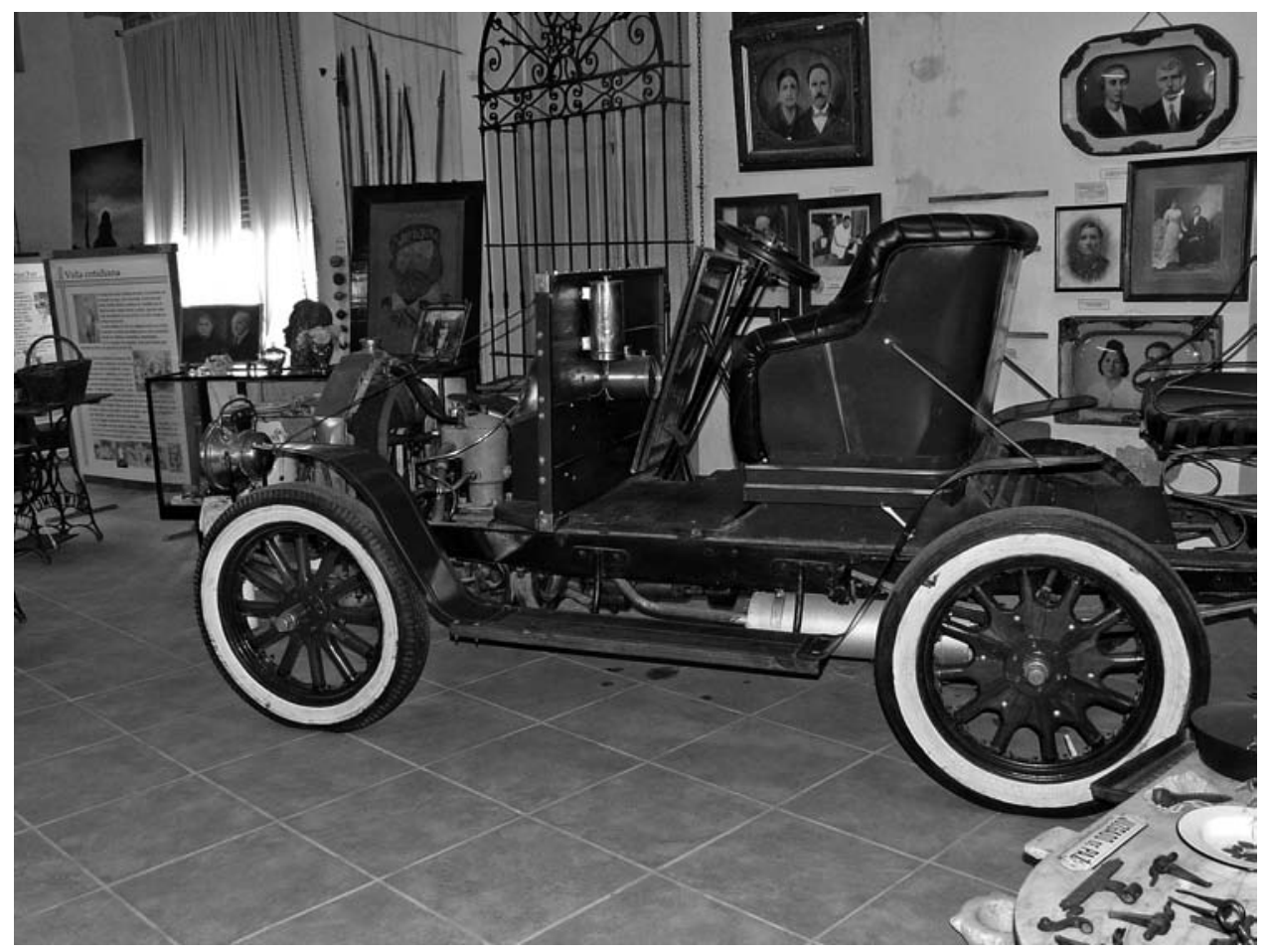

Fото 5. Museo Casa de Cultura de Tapalqué. Objetos, máquinas y fotografías cedidos por las familias del municipio. Foto: Jesús Bustamante, agosto de 2011.

dencia hasta los fusiles Rémington que tan importantes fueron para el cierre de la lucha con el indio, y que le da a este museo una cierta especificidad; así como la extensión que esta comunidad quiere dar a la exhibición de su trayectoria en el tiempo, que alcanza a objetos de tecnología mucho más reciente, como radios y televisores propios de la década de 1950.

No obstante, a pesar de la clara presencia indígena en general y de indios amigos en particular en los orígenes de Tapalqué (y en su periferia actual), el nativo no ocupa un lugar diferente al de otros museos que, como este y el Julio de Vedia, asocian el inicio de su asentamiento al avance poblacional en la lucha contra el indio. Es decir, la presencia de este último primero como indio asociado a la fauna paleozoica, más tarde el indio «primitivo», y finalmente la lectura del avance poblacional únicamente como la lucha de la civilización contra el indio «bárbaro», que solo en estas tres perspectivas entra en el museo. Dada la importancia de los indios amigos en la zona y la antigüedad de su asentamiento (debe tenerse en cuenta que solo durante dos años hubo enfrenta- 


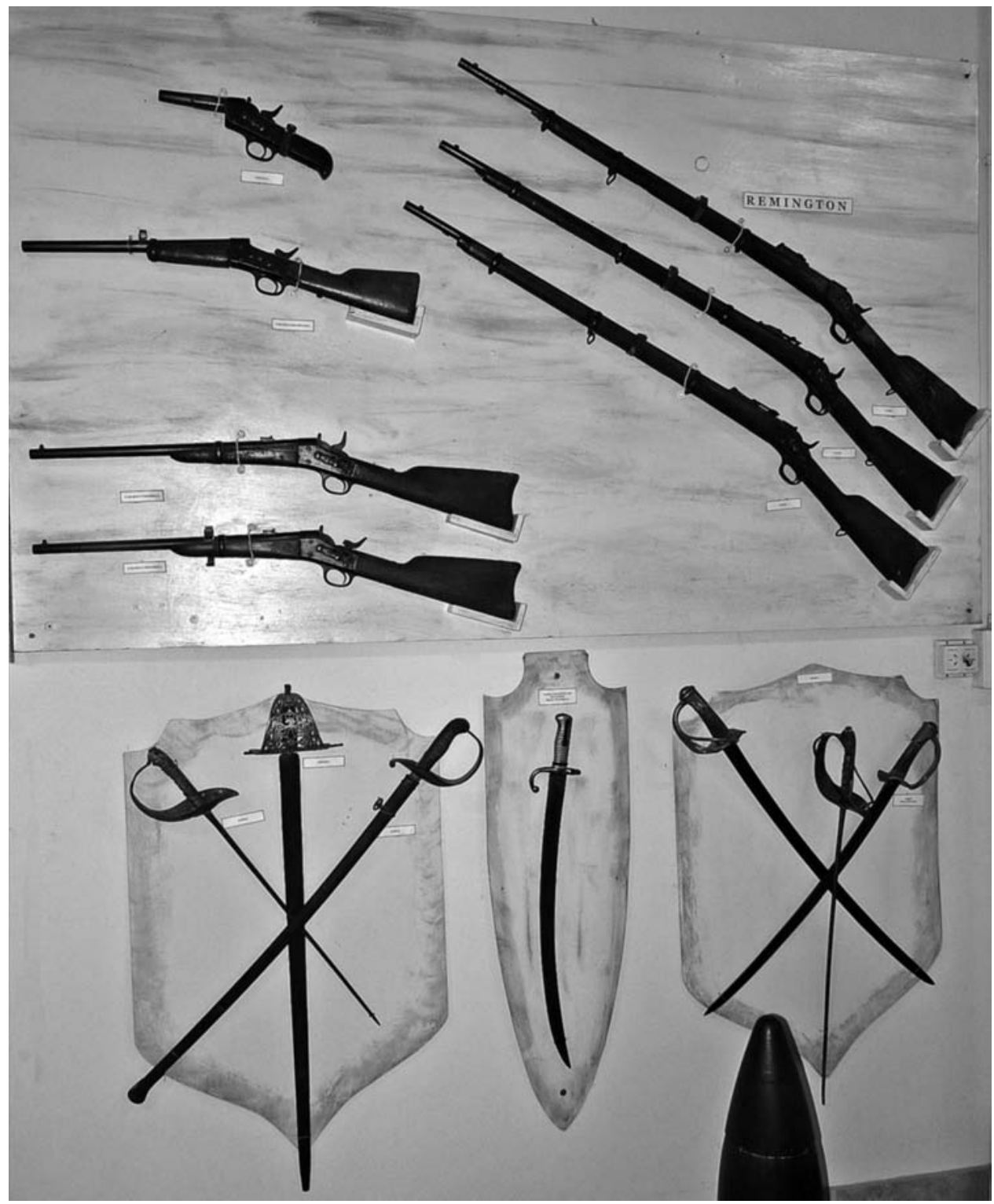

Fото 6. Museo Casa de Cultura de Tapalqué. Breve muestra de la colección de armas. Foto: Federico W. Mauriño, agosto de 2011. 
mientos entre estos y la provincia), esta forma excluyente de ver a la población indígena es al menos sorprendente. No resulta ocioso destacar que hay testimonios de los años setenta y ochenta del siglo XIX que señalan que ante el peligro de indios desconocidos la población de la última Tapalqué recurría a los auxilios del fuerte cercano, que estaba al mando de un «capitanejo» ${ }^{14}$. Este último término corresponde sin ninguna duda a la jerarquía de cargos de los indios amigos en las milicias ${ }^{15}$.

Dentro de este enfoque general se está introduciendo actualmente, como una cuña, el descubrimiento de restos arqueológicos del antiguo fuerte de Tapalqué Viejo, cuyas excavaciones son llevadas a cabo por la Universidad de Olavarría. Esto ha hecho que las fuerzas vivas del lugar comiencen a prestar atención a la presencia actual de población indígena, aunque por el momento esta última solo está representada en el museo por la fotografía de una mujer de la familia Catriel recientemente fallecida, que fue una figura de maneras peculiares y muy conocida sobre todo en la vecina ciudad de Azul. El interés del museo por los descubrimientos arqueológicos de Tapalqué Viejo es evidente, y ha destinado los dos lados de una pantalla dispuesta en forma de biombo a la exhibición de láminas y carteles a ellos referidos. Queda por saber hasta qué punto conseguirán entrar en colaboración con los equipos a cargo de las excavaciones, y si esto modificará el discurso expositivo una vez regresado el museo a sus antiguas instalaciones.

Un caso particular dentro de estos museos pot pourri es el que corresponde a la bella ciudad de Trenque Lauquen, que mencionaremos brevemente. Se trata de una localidad de fundación tardía, ya que se remonta a 1876, momento en que ya se había acordado la ofensiva final conocida como Conquista del Desierto $^{16}$. El museo fue instaurado por las fuerzas vivas de la comunidad, que son también quienes se ocupan de su mantenimiento. El recorrido, de fuerte contenido evolutivo, se inicia con una maqueta de un gliptodonte en tamaño natural. El seguimiento del origen de la tierra y la evolución botánica y zoológica se apoyan, por un lado, en láminas y objetos a veces incongruentes

14 Manuscrito que contiene el Diario de Julia Marmisolle, nieta de uno de los fundadores del tercer Tapalqué (manuscrito autografiado en noviembre de 1947). Nuevamente debo agradecer a la actual encargada del Museo Casa de Cultura de Tapalqué el haberme facilitado la lectura de este interesantísimo documento original, que merecería una publicación en toda regla.

15 Los indios amigos, que se integraron en las milicias desde 1830 como tropas (es decir, no solo como baquianos o exploradores), respondían al siguiente escalafón: coronel, capitanejo, tenientejo, alferejo, sargento, cabo y soldado. Quijada, 2011.

16 Sobre la historia de Trenque Lauquen, puede verse Estévez, 2000. 
- como una colección de dinosaurios de juguete hechos en plástico-; por otro, en un breve pero interesante conjunto de restos líticos, fósiles y alfarería. A partir de allí se despliega un conjunto de fotografías y objetos que representan la memoria colectiva de la comunidad.

La miscelánea colección incluye piezas como el sillón de la primer barbería que funcionó en la localidad, referencias fotográficas al primer telégrafo - elemento fundamental en el último tramo de la Conquista del Desierto- o una sorprendente foto del primer toro fino, de la raza Aberdeen Angus, que fue importado de Inglaterra por un estanciero del lugar a finales del siglo XIX. No se ha incluido en cambio otro tipo de objetos propios de memorias familiares, como los conocidos trajes de novia, las máquinas Singer o los adornos de porcelana. Hay una voluntad de documentar el poblamiento de la ciudad, más que los recuerdos de los abuelos fundadores o el avance tecnológico. Asimismo, estas y otras expresiones del asentamiento de origen europeo se complementan con imágenes y objetos de los primeros pobladores indígenas de Trenque Lauquen. Inician el recorrido las conocidas fotografías del cacique Pincén, dirigente de la tribu que ocupaba estas tierras antes de la creación de la ciudad; aunque era un indio hostil, Pincén fue defendido como «indio argentino» por algunos de los fundadores - en particular el comandante de las milicias Conrado Villegas - , pues así se consideraba Pincén a sí mismo frente a las huestes «chilenas» de Calfucurá. El recorrido se continúa con imágenes de pobladores indígenas del lugar, identificados con nombre y datos junto a objetos que pertenecieron a individuos de esta etnia en el periodo posterior a la aplicación del ius soli y que son fácilmente reconocibles por los ciudadanos de cierta edad (como el instrumento de bronce del llamado «indio trompeta», que en su juventud fue indio amigo y «trompa» del ejército, y que décadas más tarde se convirtió en un personaje cotidiano entre la población de Trenque Lauquen).

Aunque la representación del indio poblador no está expresada con la exhaustividad y en los términos que serían deseables en el siglo XXI, lo cierto es que puede encontrarse en este museo un reconocimiento de su presencia que se recorta de forma apreciable contra el telón de fondo del silencio clamoroso que hemos encontrado en otros museos de frontera.

\section{Museos «culturalistas»}

Los museos pot pourri estudiados en el apartado anterior contrastan con la voluntad científica del museo «culturalista». En este caso nos referiremos a una institución con vocación arqueológica que se encuentra en la población de Olavarría, fundada en 1867 por el reconocido ensayista y militar Álvaro Ba- 

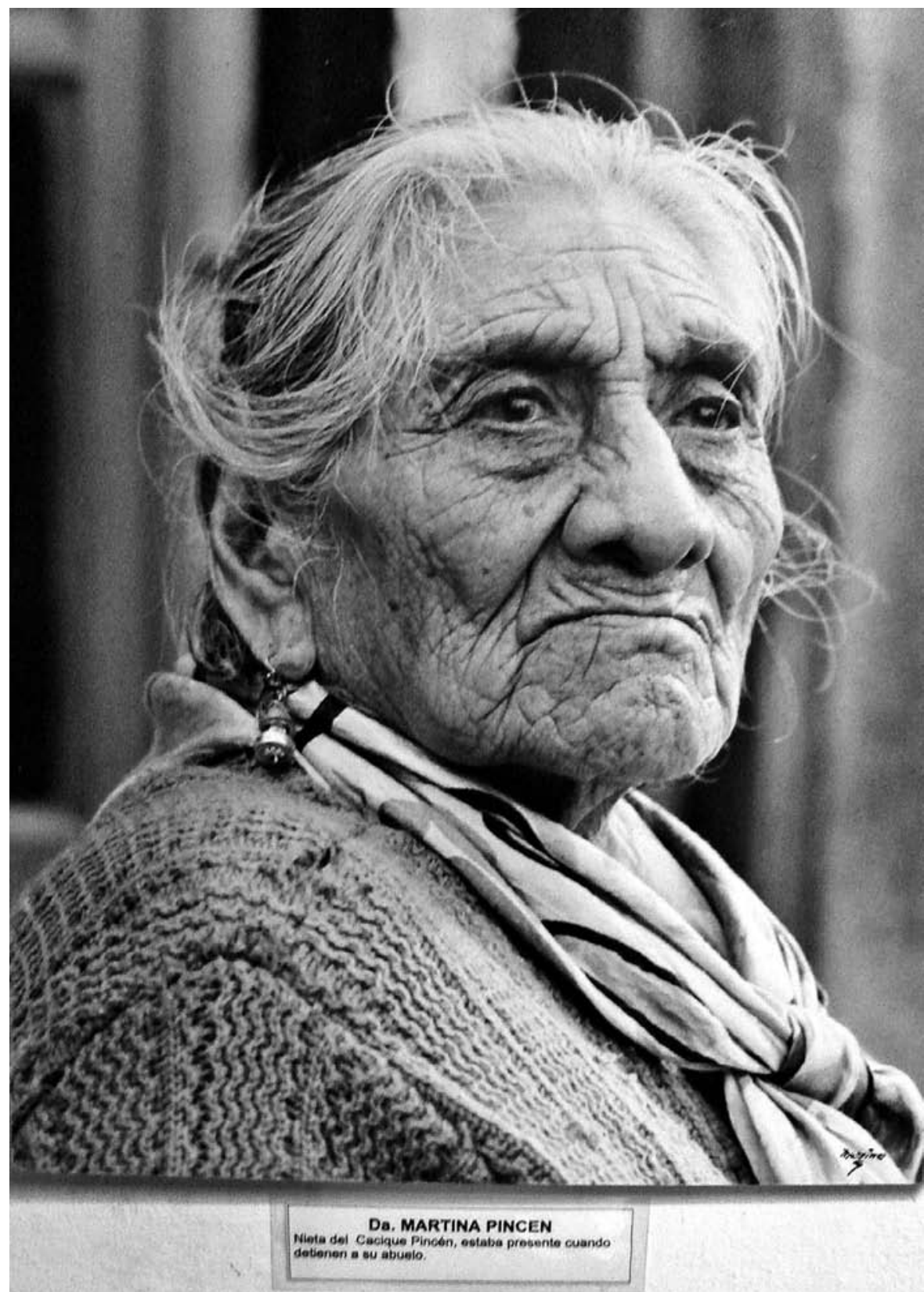

Fото 7. Museo Municipal de Trenque Lauquen. Doña Martina Pincén, nieta del último cacique autónomo de la zona. Foto: Federico W. Mauriño. 


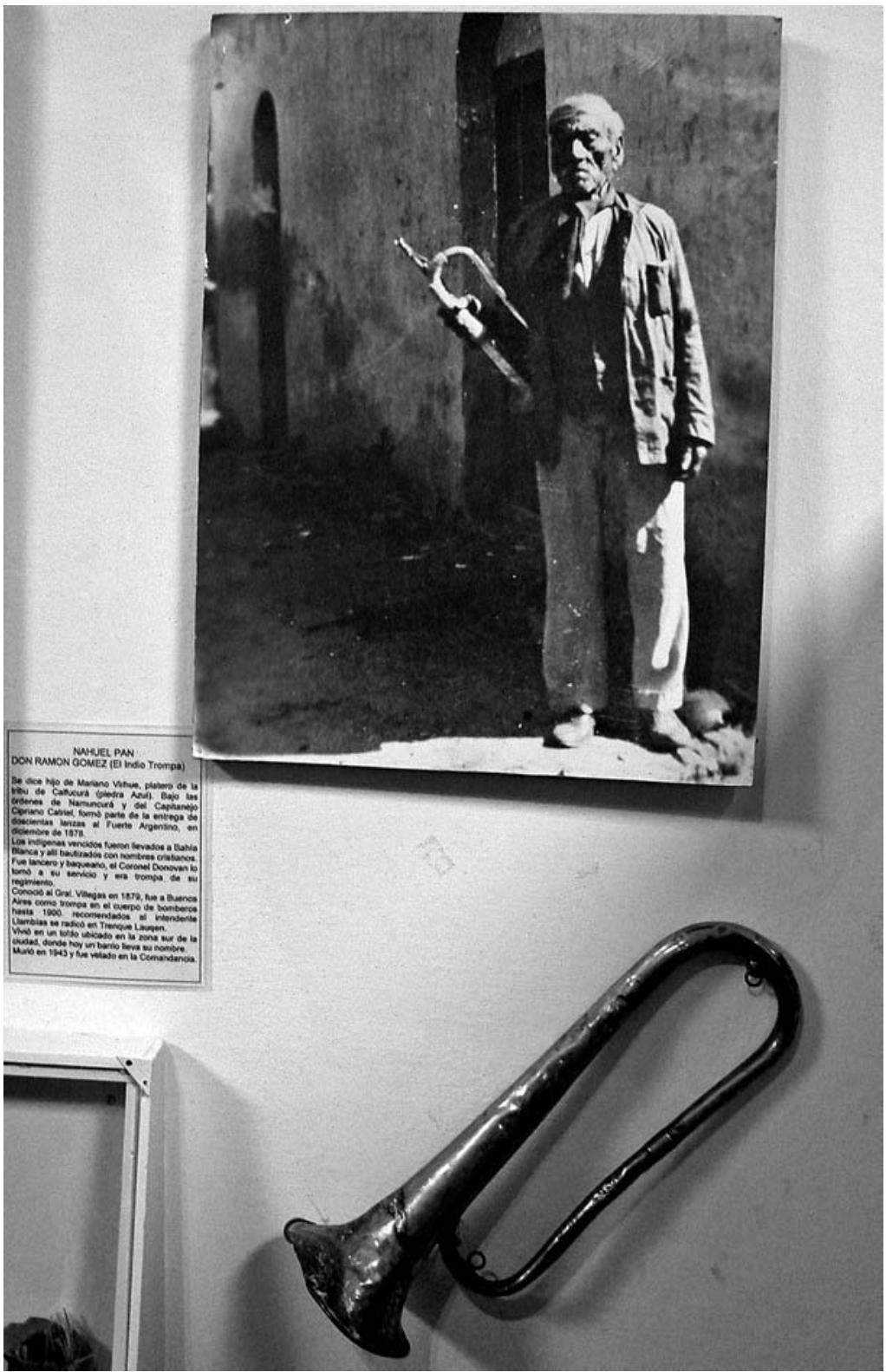

Fото 8. Museo Municipal de Trenque Lauquen. Instrumento musical y fotografía del llamado «indio trompeta», personaje cotidiano en la ciudad en la década de 1940. Foto: Federico W. Mauriño. 
rros y elevada al rango de ciudad en 1908. A diferencia de otras localidades cercanas, debe su dinamismo no solo a la ganadería y la agricultura sino a la industria cementera, que permitió una atracción de capitales que ha dotado a la ciudad — de más de 100.000 habitantes - de una especial pujanza. Olavarría se caracteriza además por acoger la universidad de la zona, cuyas secciones de antropología y arqueología son particularmente activas. Pero lo más importante para nuestro tema es que, años antes de la fundación de la universidad, las disciplinas mencionadas estuvieron estrechamente vinculadas en toda la región al Museo Etnográfico Dámaso Arce de esta ciudad. Con el telón de fondo de avatares políticos que a lo largo de algunas décadas impidieron el avance de estas disciplinas en las principales instituciones universitarias de la Argentina, el museo asumió el auténtico papel pedagógico y de investigación que los creadores de los museos decimonónicos aspiraban para sus instituciones ${ }^{17}$.

El inicio de este museo fueron las colecciones de piezas artísticas y antigüedades mobiliarias, pero también de restos fósiles y alfarería prehispánica reunidas por el orfebre y figura epónima del museo, Dámaso Arce. En 1920 y desde su propia casa de la ciudad de Olavarría Arce abrió sus colecciones al público, actuación que duró hasta 1942, año de la muerte del fundador. En 1961 una comisión integrada por personalidades locales decidió la fundación de un nuevo museo, esta vez de carácter municipal, basado inicialmente en las colecciones de Arce. Esta iniciativa contó con el apoyo de la Comisión de Cultura Municipal y del Museo Etnográfico de la Universidad de Buenos Aires. Para ocupar su dirección fue designado el antropólogo, arqueólogo y profesor de la Universidad de Buenos Aires Guillermo Madrazo, quien se mantuvo en el cargo hasta 1971. Fue él quien dotó al museo del perfil investigador que tanta significación revistió durante varios años, tanto para la región como para la propia modernización de las disciplinas que su director aspiraba a desarrollar.

Lo cierto es que desde su posición en el museo de Olavarría, Madrazo promovió la descentralización de la investigación ${ }^{18}$ mediante nuevas instituciones

17 Para la historia de la vinculación del Museo Etnográfico Dámaso Arce con el desarrollo de la antropología y la arqueología nos estamos apoyando en el muy interesante artículo de Leonís Mazzanti, 2005.

18 Dos circunstancias relacionadas favorecieron esta descentralización: por un lado, el intervencionismo académico de los gobiernos de facto que se sucedieron en la Argentina en periodos no continuos entre las decadas de 1960 y 1980, que implicaron la dimisión de muchos profesores universitarios de las principales capitales debido a la intervención de las autoridades en los planes de estudio y a la persecución policial. Por otro, la autoridad — teórica y/o efectiva- ejercida en el ámbito universitario durante esos periodos por los antropólogos Oswald Menghin - este último ex ministro de Educación de la Austria nazi- y sobre todo el italiano Marcelo Bórmida, trasladados ambos a la Argentina después de la segunda guerra mundial. 
(como la universidad de la provincia de Buenos Aires, más tarde Universidad de Mar del Plata, y el Instituto de Investigaciones Arqueológicas de Olavarría), y sobre todo fomentó la propia actividad científica realizada desde el Museo Etnográfico Dámaso Arce, con la integración de equipos de trabajo formados en los últimos debates antropológicos y arqueológicos del ámbito académico internacional, la expansión de la arqueología en el noroeste argentino y en particular en la región pampeana, y con una activa labor de expansión cultural y de publicación de revistas científicas ${ }^{19}$. Toda esta labor contribuyó «a la legitimación institucional del quehacer arqueológico fuera de las universidades» ${ }^{20} \mathrm{y}$ abrió espacios donde se generaron importantes propuestas, de duradera influencia en el ámbito museístico de la provincia de Buenos Aires, como la de Floreal Palanca y otros arqueólogos, publicadas en 1972 y 1973, sobre la coexistencia del hombre con fauna pleistocénica.

Desde la perspectiva del Museo Etnográfico Dámaso Arce, la fundación del Instituto de Investigaciones Arqueológicas en 1969 implicó la división de las actividades, quedando los proyectos de investigación bajo la despendencia del Instituto, en tanto que las de extensión cultural se mantenían a cargo del museo; articuladas ambas por el mismo director y por las publicaciones periódicas. Cabe suponer que esta separación inicial se profundizó cuando fue creada la carrera de Antropología en la Universidad Nacional del Centro de la Provincia de Buenos Aires, con sede en Olavarría, en 1988.

La exposición de objetos arqueológicos y etnográficos se encuentra hoy en la primera planta del Museo Municipal Dámaso Arce, estando dedicada la planta baja a notables piezas de orfebrería, obra de su fundador, y a exposiciones de artes plásticas. Subir la escalera que conduce a la primera planta ya es una experiencia, porque está jalonada por las excelentes pinturas etnográficas de José Speroni, que complementan los murales del mismo autor existentes en el Museo de La Plata. Se trata de estudios basados en fotografías y dibujos previos y representan una india ona, una mujer principal mapuche con los no-

Durante muchos años defendieron una perspectiva teórica de sus disciplinas tan discutible como desfasada, basada en el idealismo y la fenomenología de la escuela histórico-cultural. El poder institucional ejercido por Bórmida en el ámbito de la antropología y la arqueología mantuvo alejados de las aulas de las principales universidades los debates y nuevas teorías que se desarrollaban en el ámbito internacional. Este vacío fue convenientemente llenado por las actividades del museo Dámaso Arce y por el Instituto de Investigaciones Arqueológicas de Olavarría.

19 Dos revistas científicas - Revista Etnia y Actualidad Antropológica- y una colección de monografías sobre temas de arqueología y antropología fueron publicadas por el museo. Debe agregarse además la creación de una biblioteca especializada. Mazzanti, 2005.

20 Idem. 
tables abalorios de plata que atestiguan su jerarquía, así como varias pinturas vinculadas a los malones de la segunda mitad del siglo XIX. La exhibición propiamente dicha la inicia un gran mapa que mediante pequeños carteles sobreimpuestos indica el nombre de distintas etnias que han habitado el territorio argentino, en los que se cruzan, sin sentido diacrónico, clasificaciones lingüísticas (guaraní), arqueológicas (diaguita) o etnohistóricas (charrúas, pampas). Este cruce de clasificaciones es expresivo de una representación culturalista, en la que se elimina la noción del tiempo y de las relaciones entre los grupos, y en la que la objetivación de la pieza responde a la del antropólogo o antropólogos que intervienen en dicha clasificación. Se erige también como símbolo de una de las características de la exposición tal como se encuentra actualmente: el cruzamiento de una diversidad de criterios clasificatorios y expositivos que expresa los cambios y avatares del propio museo.

Otros dos objetos de buen tamaño señalan la entrada a las exposiciones: la reproducción de un fresco de pinturas rupestres con las clásicas manos, círculos y perfiles de guanacos con sus típicos colores rojo, blanco y negro, así como el caparazón fósil de un gliptodonte. En las paredes de este espacio central destacan las referencias a la cohabitación del hombre con la fauna extinguida y la exhibición de objetos - como las boleadoras - cuyo uso cruza varios siglos, desde el periodo prehispánico a finales del siglo XIX. A partir de allí, las distintas salas se van abriendo en abanico.

A la izquierda de esta sala central se despliega la parte más cuidada del discurso expositivo, que se ocupa de la región pampeana y que corresponde, en la división por áreas culturales que caracteriza al museo, a los «hombres de la tierra». Se trata también de la sección más renovada. Varias cosas son destacables en esta parte de la exposición. Por un lado, las boleadoras de tradición secular ceden paso a un utillaje más reciente y de manejo aún más mestizo que aquellas: ponchos, botas de potro, estribos, lazos, astas de vacuno, mates y pavas $^{21}$ cuya utilización a lo largo del siglo XIX fue propia de la cultura de la pampa independientemente del origen étnico de quienes los utilizaban, fueran indios o gauchos criollos.

Por otro, se ha retirado la clásica referencia al enfrentamiento entre «bárbaros y civilizados». Más aún, se ha incorporado un discurso historiográfico de contenido bastante reciente que explica, a partir de las nuevas propuestas de las disciplinas etnohistórica e histórica, la trayectoria de los grupos indígenas de la región en el tiempo, su papel en el proceso de avance poblacional decimonónico, las luchas por la tierra y — lo que es poco común en estas institu-

21 Suerte de tetera de metal para calentar agua, imprescindible en la confección del mate. 


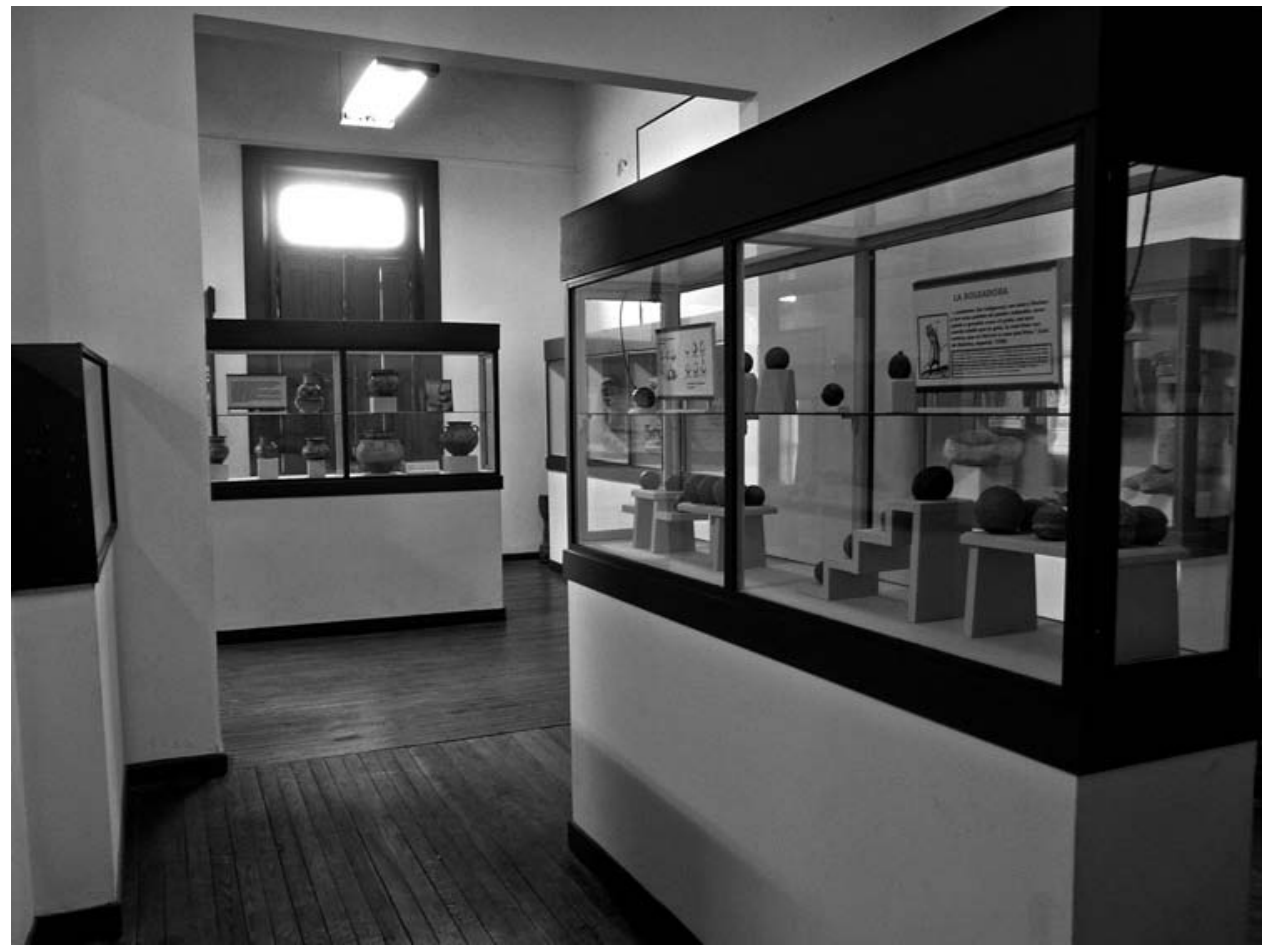

Fото 9. Museo Etnográfico «Dámaso Arce» de Olavarría. Sala central con una vitrina dedicada al uso de las boleadoras. Desde allí se abren otras salas, como la que se ve al fondo destinada a los «hombres de la montaña» (noroeste). Foto: Jesús Bustamante, agosto de 2011.

ciones - sus cruzamientos con la población no indígena y la formación de una sociedad de frontera. Estas y otras perspectivas de la nueva historiografía son desarrolladas en un conjunto significativo de cartelas. El mismo discurso expositivo - es decir, señalando las contingencias históricas - vincula a esta parte de la exhibición con la correspondiente a los mitificados habitantes de la Patagonia y grupos fueguinos — alakalufes y onas-, estos últimos con fuerte apoyo de fotografías de viajeros ingleses y franceses del siglo XIX.

Esta visión renovada, con un importante contenido proveniente de la bibliografía etnohistórica de las últimas décadas, contrasta con la exhibición más tradicional de áreas como las zonas altas del noroeste («hombres de la montaña») o las tierras bajas chaqueñas («hombres del bosque»). La primera (noroeste, Cuyo y sierras centrales) está basada sobre todo en alfarería, referencias a la deformación craneal, puntas de metal, hondas y otros utensilios de 


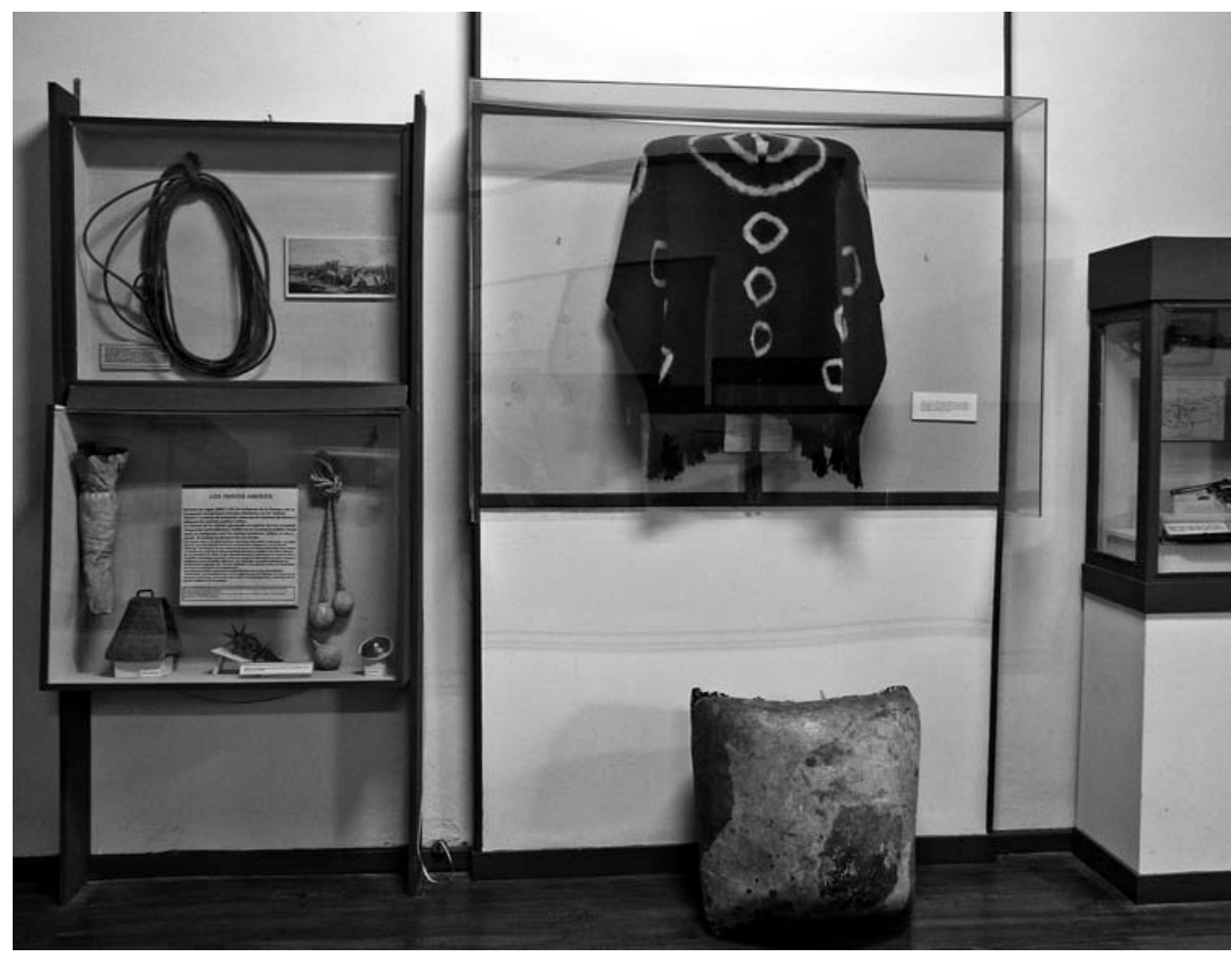

Fото 10. Museo Etnográfico «Dámaso Arce» de Olavarría. Objetos y prendas de la zona rural bonaerense durante el siglo XIX. Eran utilizadas tanto por indios como por criollos. Foto: Jesús Bustamante, agosto de 2011.

la cultura andina, en general objetos antiguos apoyados en fotografías folklóricas en color, hechas hace pocas décadas. Si esta parte de la exhibición se fundamenta sobre todo en la arqueología, la de las tierras bajas - zona chaqueña- es de un marcado carácter etnográfico y cruza distintos aspectos como las lenguas, las armas, y la producción tradicional de objetos de uso cotidiano. Una buena colección de máscaras y el apoyo explicativo de unos maniquíes son parte importante de la exposición.

A diferencia de los museos pot pourri antes reseñados, el Museo Etnográfico Dámaso Arce es una institución con voluntad científica desde sus inicios en 1961, centrada - como su nombre lo indica - en la etnografía y disciplinas afines. Vocación que surge, en su caso, de una dedicación inicial a la tarea investigadora muy distinta de la inspiración comunitaria destinada a salvaguardar la memoria de la colectividad, propia de los restantes museos etnológicos 


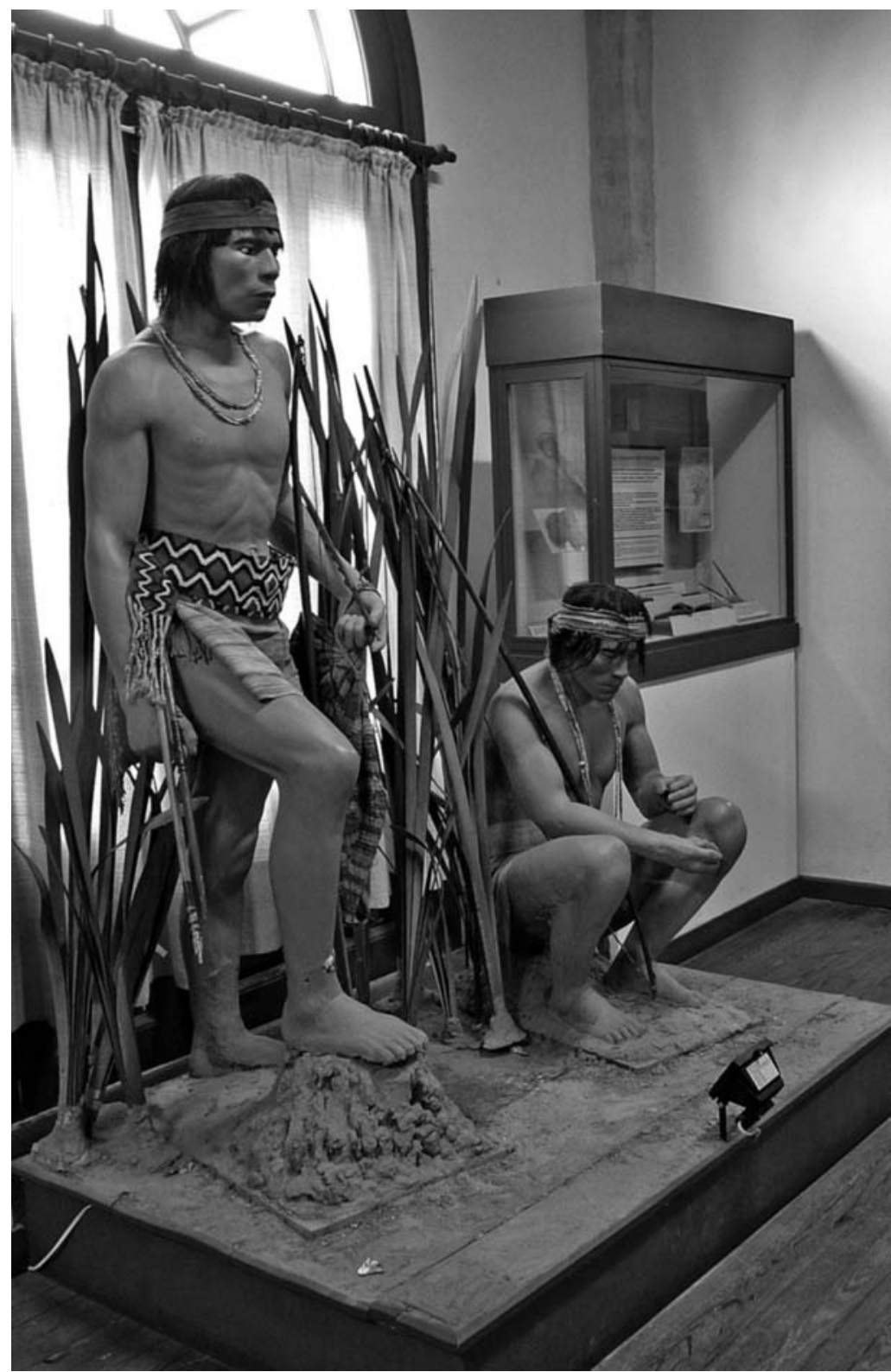

Fото 11. Museo Etnográfico «Dámaso Arce» de Olavarría. Maniquíes que muestran a los indios chaqueños del siglo XIX («hombres del bosque»), con sus armas y abalorios. Foto: Jesús Bustamante, agosto de 2011. 
de la región. Asimismo, la historia del Museo Etnográfico está presente en esta exposición, tanto en sus colecciones como en el peso de un discurso basado sobre todo en una división por áreas culturales sin interacción entre ellas (hombres de la grasa, de la tierra, de la montaña, del bosque) y una diversidad de criterios expositivos (etnográfico, arqueológico, etnohistórico). La renovación parcial de la exhibición va asociada, no casualmente, a la arqueología y sobre todo a la etnohistoria más recientes, las de la región pampeana.

\section{Museos «estetizantes»}

Al sureste de Olavarría se encuentra la muy interesante ciudad de Azul, que remonta su origen a la fundación del Fuerte San Serapio Mártir del Arroyo Azul, en 1832. En 1895 fue declarada ciudad. Muchas casas decimonónicas de bella arquitectura y una ambición cultural que se expresa en su cuidado urbanismo, en la cantidad de bibliotecas públicas y en sus elaborados museos dan atractivo a esta población, cuya centralidad dentro de la provincia puede medirse tanto en términos geográficos como históricos.

Otra de sus singularidades es haber sido nombrada por la UNESCO «Ciudad Cervantina». Esto se debe, principalmente, al hecho de que alberga una extraordinaria biblioteca en la que se guarda un número ingente de ediciones del Quijote, elegidas tanto por su antigüedad como por la originalidad, la rareza, la calidad de la edición o de las ilustraciones, o la voluntad de incorporar una notable variedad de lenguas. Esta biblioteca se aloja en la que fuera la propia casa del coleccionista, Bartolomé Ronco, conocida e influyente figura que vivió y ejerció allí la abogacía en la primera mitad del siglo $\mathrm{XX}^{22}$. Hombre dado a reunir todo tipo de objetos, siempre de gran calidad, a él se deben también las extraordinarias piezas que conforman la base del museo etnográfico de la localidad y que incluyen objetos araucanos y pampas, platería gauchesca y mapuche, cerámica indígena, tejidos, armas e importante documentación referida al Azul.

Por su iniciativa, en 1940 comenzó a plasmarse la idea, vinculada a la Biblioteca Popular de la localidad ${ }^{23}$, de dotar a esta institución de un museo y ar-

22 Bartolomé Ronco es considerado un pionero de la cultura en su localidad. Fundador de la Universidad Popular «José Hernández», editó las revistas Biblos y Azul y organizó exposiciones y conferencias con especialistas y hombres de letras provenientes de distintos países de América Latina y Europa. Creó la Agrupación Artística Maná y dejó obras como Voces Araucanas, Toponimia histórica y actual de Azul, diccionarios folklóricos y trabajos de índole judicial.

${ }^{23}$ La Biblioteca Popular de Azul tuvo su origen en una iniciativa de la «Sociedad Cosmo- 
chivo que contara «la historia de un pueblo surgido en plena pampa en el año 1832; y que fuera además testigo de importantes episodios que hicieron a la historia del país» ${ }^{24}$. Museo que surge, por tanto, con vocación comunitaria pero, como veremos, con una factura, una calidad y - actualmente - un discurso expositivo originales.

En la casa de dos pisos más antigua de la ciudad $(1854)^{25}$ se guardan las colecciones del Museo Etnográfico y Archivo Histórico «Enrique Squirru».

Se trata de un museo muy bien cuidado, con una estructura institucional y financiera muy especial. Está basado sobre todo en las colecciones antes mencionadas del abogado y erudito local, Bartolomé Ronco, que al cederlas a la ciudad pidió que no pasasen a manos estatales. Se constituyó entonces una comisión directiva que trabaja ad honorem. No obstante, el municipio ha dotado fondos para la asignación de un director y una museógrafa.

A la izquierda de la entrada, con portón colonial de herrajes, se abre un amplio espacio dividido en dos salas. Aunque hay otras salas en el museo ${ }^{26}$, este es sin duda el ámbito más importante del mismo, el más cuidado y el que muestra la voluntad del discurso expositivo. Ambas son de una gran belleza. La que da entrada al recinto se divide en dos conjuntos, a derecha e izquierda, que muestran magníficas piezas de plata de factura mapuche (derecha) y criolla (izquierda). El primero incluye bellas muestras de pectorales de plata, utilizados por los hombres, así como los collares, pendientes, brazaletes y topos

polita», asociación vinculada sobre todo a la comunidad de origen francés asentada en la ciudad, y estaba destinada a la «educación pública democrática» de la población. Luego de varios intentos, su fundación definitiva se produjo en 1892. Además del Museo Etnográfico «Enrique Squirru», varias instituciones se desprendieron de la Biblioteca Popular, como la Asociación Ameghino, interesada en temas de la paleontología, la arqueología, la geología y la fauna y flora locales; la Biblioteca Infantil Circulante, la Biblioteca Carcelaria y la Sección Archivo de Azul. Este último era un nutrido repositorio de la documentación del lugar que más tarde pasaría al Museo Etnográfico Squirru y ha seguido creciendo hasta el día de hoy. Fernández, 2008.

${ }^{24}$ Museo Etnográfico y Archivo Histórico «Enrique Squirru». Azul, Talleres Gráficos de Impresos San Cayetano, 2000. Agradezco a los directivos del Museo el haberme facilitado esta publicación, así como la de Fernández, 2008.

25 El museo se fundó definitivamente en 1945, y a la antigua casa de dos pisos antes citada se le agregó el terreno adyacente, lo que incrementó el espacio para exhibiciones, archivo y almacenamiento.

${ }^{26}$ Las restantes salas guardan cuadros, alfarería, armas, fotos y máquinas para la práctica de la fotografía e incluso piezas curiosas, como la primera centralita telefónica que operó en la ciudad. No obstante, por su interés de contenidos y de discurso nos centraremos en las salas principales antes citadas. 


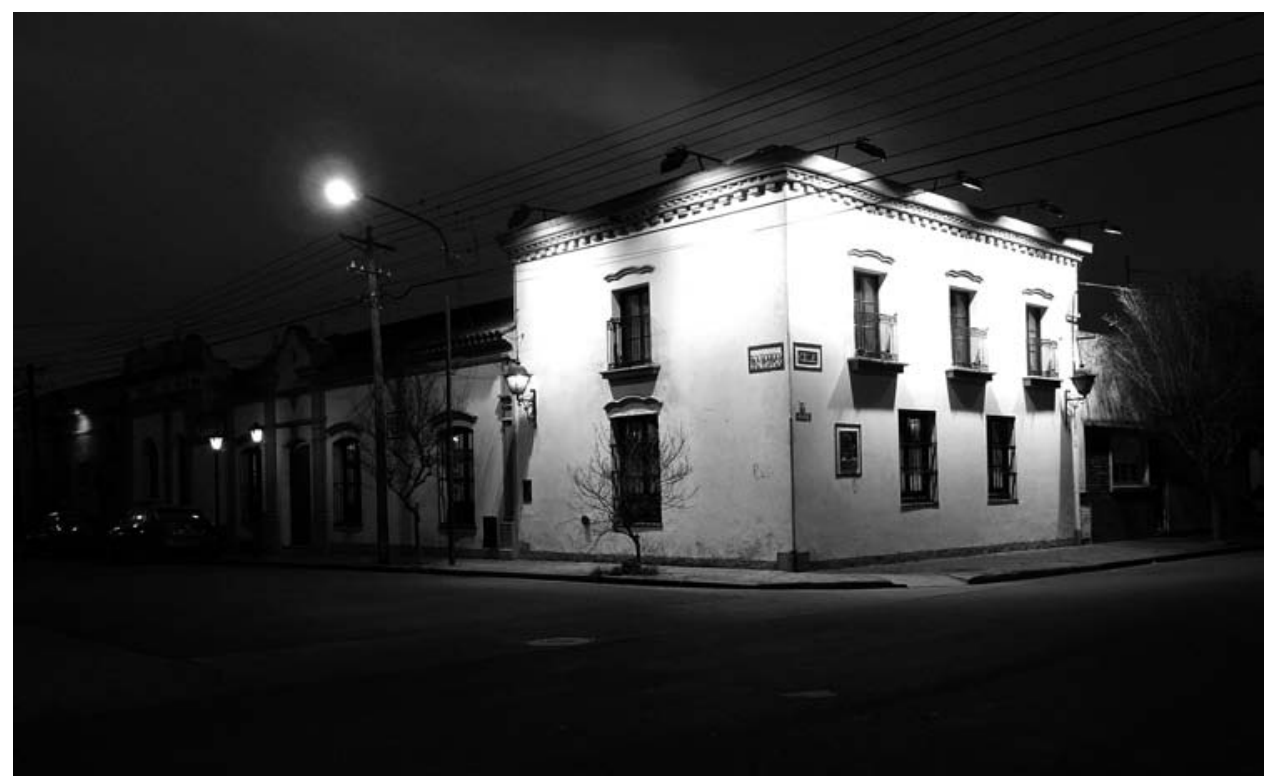

Fото 12. Museo Etnográfico y Archivo Histórico «Enrique Squirru» de Azul. Fotografía de la casa que alberga al museo, la más antigua de dos plantas de la localidad (1854). Foto: Jesús Bustamante, agosto de 2011.

usados por las mujeres, que con la calidad y cantidad de estos señalaban su jerarquía dentro del grupo.

Magníficos textiles completan la muestra. El segundo constituye una excelente colección de platería vinculada al uso del caballo (estribos, cabezadas y riendas recamadas en plata), y los ajuares del hombre de campo que, como en el caso de las mujeres mapuches, en la cantidad y calidad mostraban la jerarquía del portador. En este sentido destacan las rastras, complicadas piezas de plata y oro que unen las dos partes de cuero que conforman el cinturón y que llevan entretejidas monedas varias y botones, a veces con monograma; así como rebenques con mango de plata y vainas de cuchillo con notables cincelados en ese metal.

En este lado del muro se abre una bella puerta de rejería que conduce a una pequeña sala con una muestra de objetos decimonónicos de calidad. Entre piezas de porcelana, bronce y cobre de muy buena factura, destaca una magnífica colección de mates antiguos - de plata y oro, metal blanco, cobre y madera, calabaza, hueso y asta los de hechura americana; de loza (procedentes de Alemania) los de hechura europea. Las infaltables bombillas de plata y oro completan la muestra. 


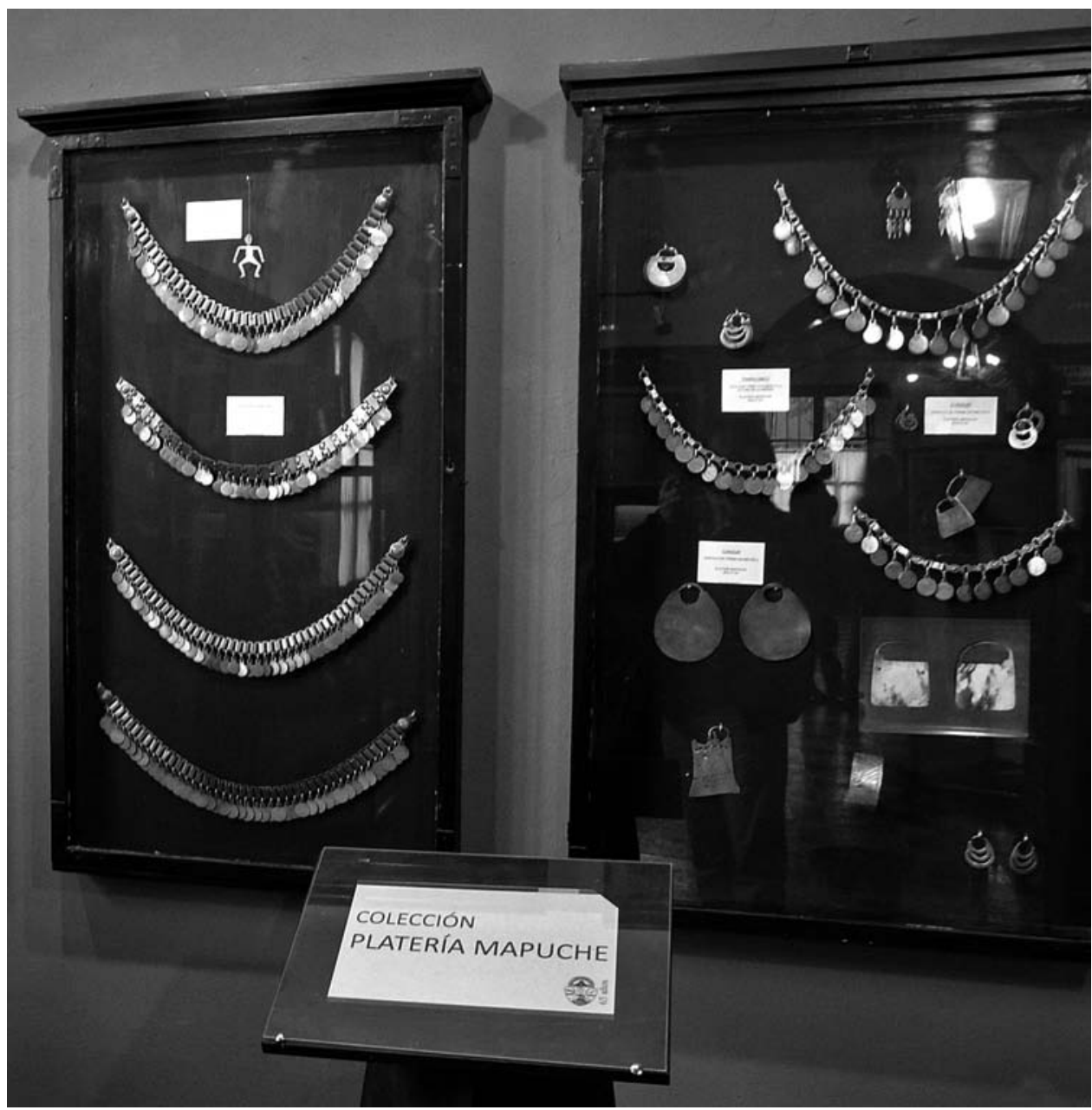

Fото 13. Museo Etnográfico y Archivo Histórico «Enrique Squirru» de Azul. Parte de la colección de platería mapuche. Collares, pendientes y brazaletes. Foto: Jesús Bustamante, agosto de 2011

De tal forma ambos lados de esta gran sala, derecha e izquierda, están destinados a mostrar respectivamente la cultura indígena y la criolla. Pero al frente de ella se abre un último espacio que, aprovechando la altura del antiguo edificio de dos plantas, muestra una colección de elementos utilizados en las tareas y actividades del campo. Lo más sorprendente es la presencia del mostrador y enrejado de una pulpería, trasladados completos al museo. El propósi- 


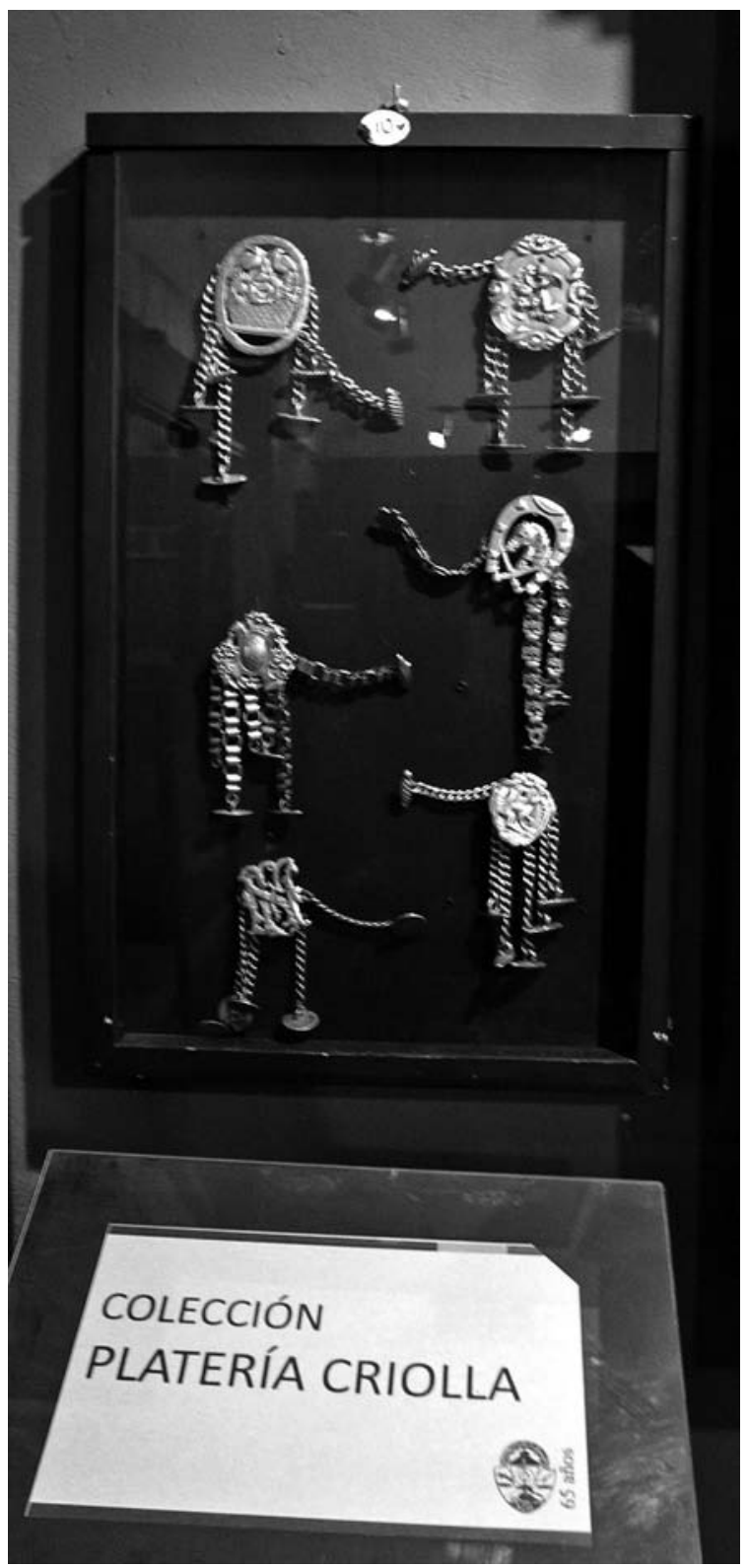

Fото 14. Museo Etnográfico y Archivo Histórico «Enrique Squirru» de Azul. Parte de la colección de platería criolla. Rastras (piezas centrales para el cinturón). Foto: Jesús Bustamante, agosto de 2011. 
to de esta sala es representar el encuentro de las dos culturas - la indígena y la criolla - que concurren en las tareas rurales, y de la inmigración, identificada con la pulpería que generalmente estaba regentada por individuos pertenecientes a las oleadas inmigratorias que tan abundantes se hicieron en la segunda mitad del siglo XIX. La pulpería, lugar donde se compraban todo tipo de vituallas, desde alimentos hasta objetos para la tareas del campo, era también el sitio donde tanto criollos como indios e inmigrantes se acercaban para beber y para pasar los ratos de ocio expresados en el juego de naipes y el canto con guitarra, y que muchas veces se convertían en duelos a cuchillo; de ahí la importancia del enrejado que protegía al pulpero y a sus productos de la violencia cotidiana, así como de los malones de grupos indígenas hostiles. Esta reja de pulpería se remonta a 1890, época en que el campo estaba ya pacificado y así lo atestigua la finura de los hierros, destinados en este caso ya más a seguir una tradición que a defensa ${ }^{27}$.

Hasta hace pocos años las salas que hemos descrito contenían muchos otros elementos indicativos del poblamiento del lugar a lo largo de los siglos XIX y XX ${ }^{28}$. Entre otros una extraordinaria colección de fotografías de los fundadores y posteriores pobladores de Azul, criollos y europeos, así como fotografías de la familia Catriel, el principal grupo indígena del lugar, de los asentamientos indios de la zona — en particular la barriada Villa Fidelidad, sita hasta el día de hoy al otro lado del arroyo Azul—, así como de la casa que el cacique Cipriano Catriel tenía en pleno corazón de la ciudad criolla, y que sorprendentemente fue derribada hace veinte años por orden de la municipalidad. Entre fotos, litografías y objetos vinculados a la población indígena del lugar figuraba una pieza única: el sello personal del cacique Cipriano Catriel, que rezaba «Cacique Mayor de las Pampas» y que se remonta posiblemente a 1855, periodo en que le fue asignado ese cargo por el dirigente liberal, y más tarde Presidente de la República, Bartolomé Mitre.

Estos objetos y sobre todo fotografías que mostraban la memoria de los grupos humanos que formaron y aún forman la ciudad de Azul han sido retira-

27 El mostrador y reja trasladados al Museo Etnográfico «Enrique Squirru» provienen de un conocido almacén de ramos generales, «Spinal de Azul», fundado aproximadamente en el año de 1890. Como contraste, en las inmediaciones de la cercana Tapalqué y en una carretera poco transitada pervive una pulpería con rejas mucho más recias que las del museo azulense. Esta pulpería, que sigue dando servicios de venta de vituallas y enseres camperos, se conserva como muestra de lo que era una instalación de estas características en la década de 1860, época de gran violencia en la frontera.

28 Por las fotografías que contiene la guía Museo Etnográfico y Archivo Histórico «Enrique Squirru», 2000, la exhibición se parecía mucho más a la de los típicos museos de comunidad que hemos descrito en los casos de 9 de Julio y Tapalqué. 


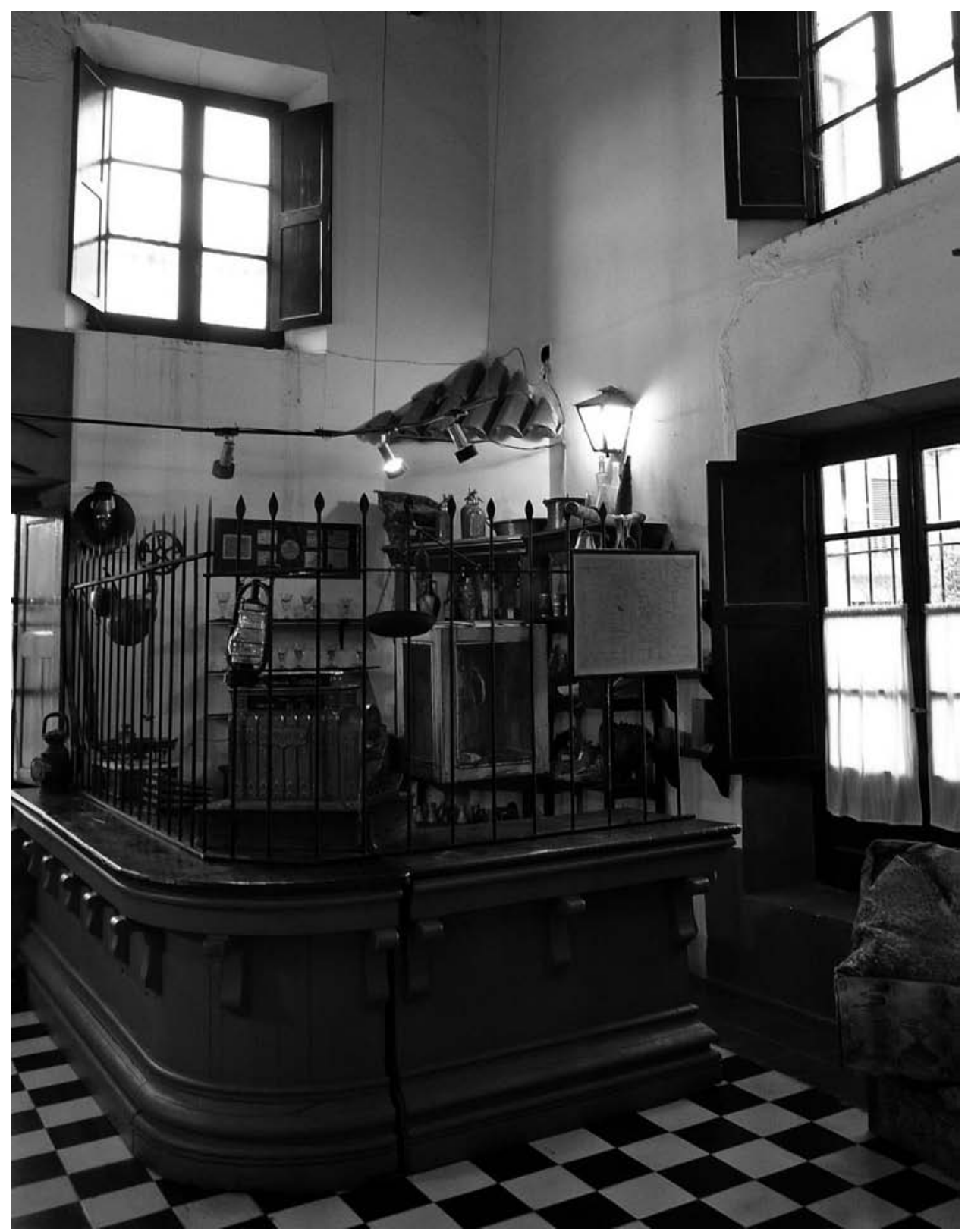

Fото 15. Museo Etnográfico y Archivo Histórico «Enrique Squirru» de Azul. Reja y mostrador de pulpería (1890). Foto: Jesús Bustamante, agosto de 2011. 
dos de la exhibición y guardados en el archivo; solo pueden verse en este último por amabilidad del personal directivo del museo y archivo, con la que tuvimos la suerte de contar. La voluntad de eludir problemas con la actual población indígena, que deja al público propio y ajeno sin un importante testimonio de la vida de la comunidad a través del tiempo, está detrás de esta decisión, así como el despliegue de un nuevo criterio expositivo que prima lo estético por encima de toda otra condición. Esta elección expositiva de carácter «estetizante», legítima sin duda, priva sin embargo a la exhibición de elementos muy valiosos, como el sello personal de Catriel y la propia colección de fotografías que son únicas por su calidad, cantidad, amplitud temática y extensión en el tiempo. Su mantenimiento hubiera permitido - a juicio de quien esto escribe - tener una visión original y sumamente interesante de los dos contingentes que contribuyeron al poblamiento de Azul desde el siglo XIX hasta la actualidad.

Como una respuesta a esta voluntad expositiva que mantiene el objeto y elimina al hombre para evitar problemas y enfrentamientos, en el Arroyo Azul (que tradicionalmente ha separado la población criolla de la indígena) se erige un busto de considerable tamaño que representa a Juan Catriel, fundador de la dinastía indígena cuyos descendientes aún ocupan el lugar. A la espalda del cacique se despliega el barrio indígena de Villa Fidelidad y a su frente, con vistas a la ciudad criolla donde su hijo Cipriano tenía casa, Catriel cruza miradas día tras día con las figuras del Quijote y de Sancho Panza, allí erigidas cuando Azul fue nombrada Ciudad Cervantina por la UNESCO, en el año de 2007.

\section{Museos «historizantes»}

El indio poblador, y además fundador de poblaciones, lo hemos encontrado con la exhaustividad que le corresponde en un único museo, el Museo del Indio de la localidad de Los Toldos, al que hemos clasificado como «historizante». No casualmente, surge en este caso de la voluntad de crónica historiográfica debida a quien dio origen a dicha institución: el Padre Meinrado Hux, religioso de origen suizo y miembro de la comunidad benedictina de Santa María de Los Toldos, fundada en 1948. El Padre Hux es un conocido historiador de las poblaciones indígenas de la pampa, que a lo largo de décadas ha recorrido los numerosos archivos municipales de la provincia de Buenos Aires, estudiando sus contenidos y publicando libros que han sido valiosísimas fuentes de información para los historiadores y etnohistoriadores que se han interesado en esos temas. 


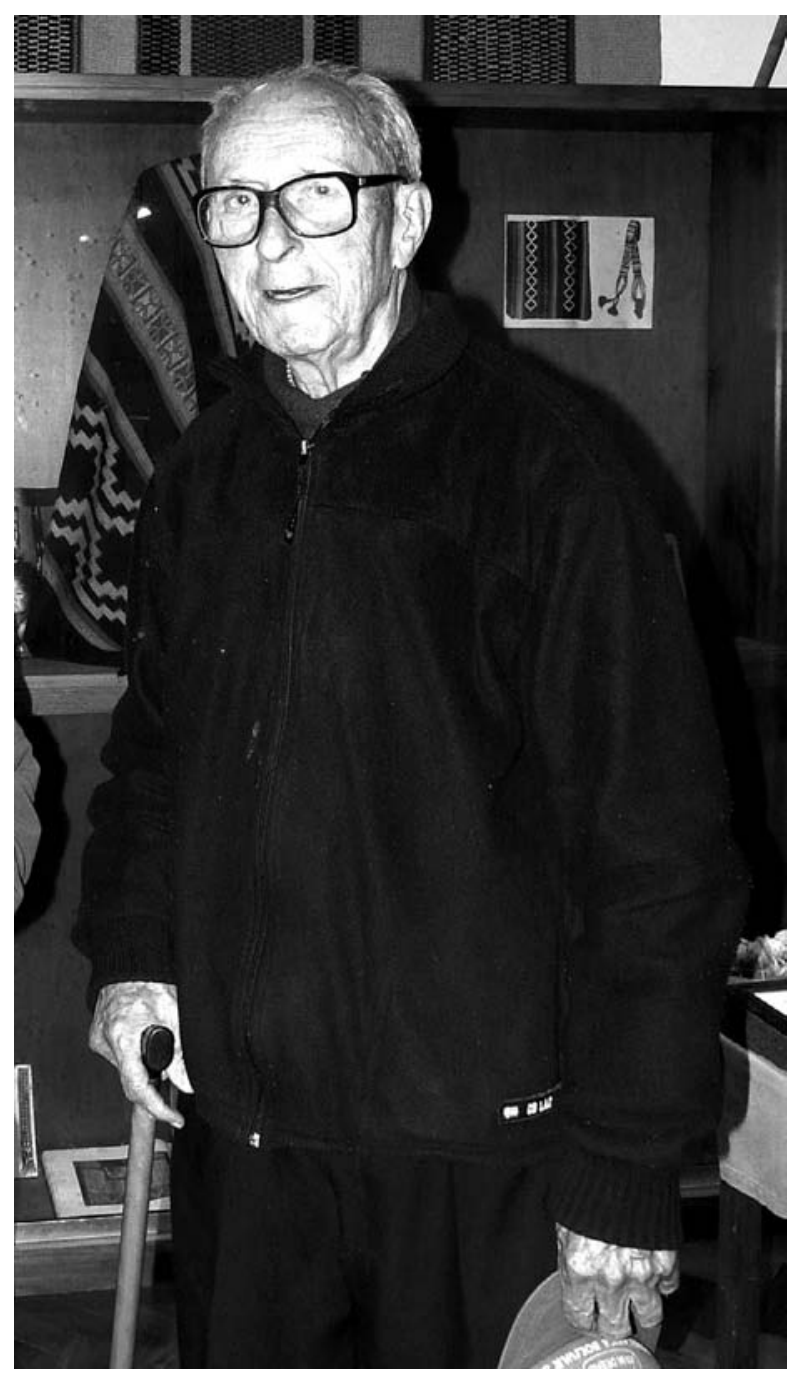

Fото 16. Museo del Indio de Los Toldos. Fotografía tomada a su fundador, el P. Meinrado Hux, en una visita al museo realizada en agosto de 2011. Foto: Jesús Bustamante.

Cuenta la historia —o quizás la leyenda — que al llegar a la recientemente fundada Abadía de Santa María el P. Hux descubrió que la numerosa población indígena, perteneciente en su mayoría al asentamiento promovido allí en 1862 por el cacique borogano Ignacio Coliqueo con el apoyo de Bartolomé Mitre, desconocía la historia de sus antecesores. Esto habría motivado su vo- 
cación de cronista de las poblaciones indígenas ${ }^{29}$, que abarcó no solo a esta parcialidad sino a otros grupos muy importantes en la época de la lucha con el indio, como los pampas, los huiliches de Calfucurá y los ranqueles. Su bibliografía es amplísima ${ }^{30}$.

La localidad de Los Toldos tiene una curiosa historia, muy vinculada a la población indígena. A finales de la década de 1850 Mitre cedió en propiedad unos terrenos a su fiel aliado el cacique Ignacio Coliqueo, que eligió un paraje con buenas aguadas en la zona llamada La Tapera de Díaz, que más tarde sería conocida como Los Toldos Viejo. En la década de 1870 un comerciante procedente de Tucumán, don Electo Urquiza, instaló allí una modesta pulpería. El establecimiento, que llevaba por nombre «El Argentino», prosperó en medio de la población indígena, a pesar de tener que hacer frente junto con los indios amigos de Coliqueo a dos formidables malones de las tribus hostiles de Calfucurá y Namuncurá ${ }^{31}$. Los buenos negocios permitieron a su dueño la compra de tierras de labor.

Cuando en 1890 las Cámaras Legislativas decidieron la prolongación del ramal ferroviario entre dos localidades cercanas, don Electo Urquizo ofreció regalar terreno para que el tramo llegara hasta su campo y erigir un próspero pueblo. Este fue el origen de la ciudad de Los Toldos, a la que Don Electo llamaba «Mi hijo» ${ }^{32}$.

Además de regalar terreno para los espacios públicos de la nueva población, Electo Urquizo dividió una parte de sus tierras en solares para promover el poblamiento y facilitó a gente de pocos recursos el acceso a los mismos. Entre los solares vendidos los hay que fueron comprados por indígenas, entre ellos descendientes del cacique Coliqueo, personas muy respetadas en la loca-

${ }^{29}$ Museo de Arte e Historia Municipal de Los Toldos, www.museolostoldos.com.ar/meinrado hux.htm

$\overline{30}$ Entre sus muchas publicaciones, señalaré los libros Caciques pehuenches (1991), Caciques huiliches y salineros (1991), Caciques borogas y araucanos (1992), Caciques puelches, pampas y serranos (2003), Coliqueo, el indio amigo de Los Toldos (2009), y las ediciones de las Memorias de Santiago Avendaño (1999), y de Manuel Baigorria (2006). Para sus numerosísimos artículos y folletos véase las entradas correspondientes en Hux (2000).

31 «Don Electo se transforma en un activo pulpero entre los indios. Su compañera lo ayudaba en la venta de vinos, yerba, azúcar. Ella preparaba pasteles y tortas fritas y confeccionaba camisas, chiripás, mantas. La clientela aumentaba y "El Argentino" tenía bien puesto su nombre, pues él era criollo y los demás pulperos, españoles. La vida también le ofreció sobresaltos. Tuvo un percance grave cuando la invasión de la tribu por parte de los indios de Namuncurá». Museo de Arte e Historia Municipal de Los Toldos, www.museolostoldos.com.ar/electo_urquizo.htm.

32 Urquizo, 1992 [1914]. En 1901 Los Toldos fue elevada al rango de ciudad, con la instalación de una delegación municipal y el registro civil. 
lidad ${ }^{33}$. Años más tarde Los Toldos resultó ser el lugar de nacimiento de uno de los personajes más conocidos de la Argentina, Eva Perón. Su original historia le ha dado a Los Toldos un perfil singular, al que debe agregarse la relevante actividad que el P. Meinrado Hux ha realizado durante varias décadas desde su monasterio benedictino, que incluye la fundación de un Museo del Indio dentro de las instalaciones de la Abadía.

El museo se extiende a lo largo de una larga sala flanqueada por vitrinas de madera noble y numerosos cuadros, fotografías y objetos en las paredes. Una buena parte de estos espacios está dedicada a la familia de Ignacio Coliqueo, en sus distintas generaciones a lo largo del tiempo. Sus hijos Simón, Antonio y Martín, con sus familias respectivas, más la esposa de Simón, Luisa Pascual de Coliqueo - todos ellos establecidos en Los Toldos o en localidades cercanas después de la aplicación del ius soli- ocupan una pared completa. A ellos se agrega la imagen marcial de Justo, tempranamente fallecido.

Un gran retrato de Simón, con su uniforme de coronel del Ejército, constituye el centro de esta parte de la exposición. Este despliegue familiar se completa con fotografías de algunas mujeres de la familia Coliqueo a principios del siglo XX, en general de actuación destacada como la «machi» María Roca a quien llamaban «Santa María»; caciques y familiares de otras tribus de la zona vinculadas a los Coliqueo (Melinao, Railef y Coñequir); así como una fotografía notable por lo poco usual, que muestra a un nutrido grupo de «hijos de caciques» reunidos en Buenos Aires en 1929. Correspondiendo a fechas más cercanas en el tiempo, ya avanzado el siglo XX, aparece un grupo de fotos de la familia Coliqueo que incluye entre otras una imagen de la capilla denominada de «La Tribu», con sus feligreses, y otra de la ceremonia con que se recordó el centenario de la muerte de Ignacio Coliqueo (2 de febrero de 1971) y en la que el discurso principal fue pronunciado por José Cayún, nieto del capitanejo Ramón Cayún.

Una serie de objetos significativos del poblamiento de Los Toldos, en sus tres grupos principales - indígenas, criollos e inmigrantes - , se despliega en las vitrinas, aunque con muy distinto grado de atención. En el primer conjunto destacan el quepí de Simón Coliqueo ${ }^{34}$, dos libros de la Abadía que contienen el «Registro de bautismos de indios de la tribu de Coliqueo, 1875», y el «Re-

33 Cuando en 1908 se establecieron los cargos comunales del partido de Los Toldos, Antonio (o Antonino) Coliqueo fue designado Juez de Paz. Su hermano Simón, que tenía casa en 9 de Julio, fue consejero escolar y jefe político del partido mitrista. A su muerte, que se produjo en Los Toldos en casa de su hermano Antonino, se celebró un gran entierro y la ciudad le dedicó un monumento. Su viuda, Luisa Pascual Coliqueo, compró un solar en Los Toldos y vivió en esa localidad hasta su fallecimiento en 1935. Urquizo, 1992: 48 y 85-86. 


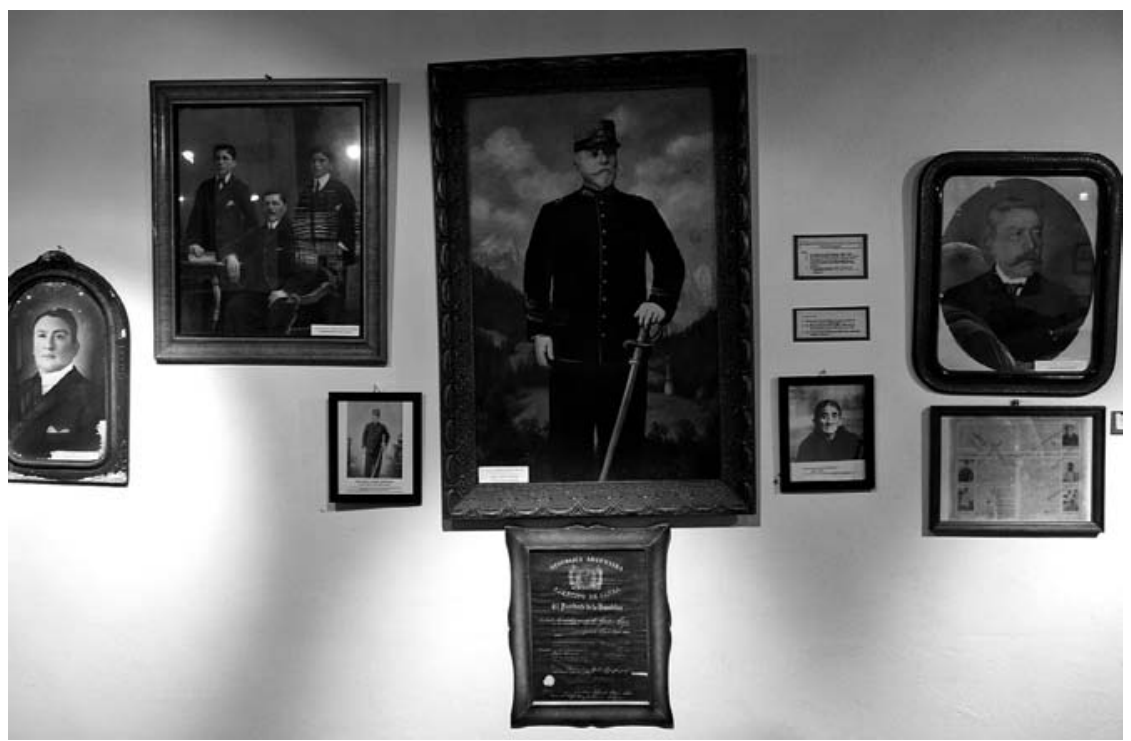

Fото 17. Museo del Indio de Los Toldos. Fotografías que muestran a los hijos del cacique Ignacio Coliqueo con sus respectivas familias, después de la aplicación del ius soli. La figura central corresponde al Sargento Mayor Simón Coliqueo, considerado héroe de la batalla de Pavón y poblador respetado de la zona. Foto: Jesús Bustamante, agosto de 2011.

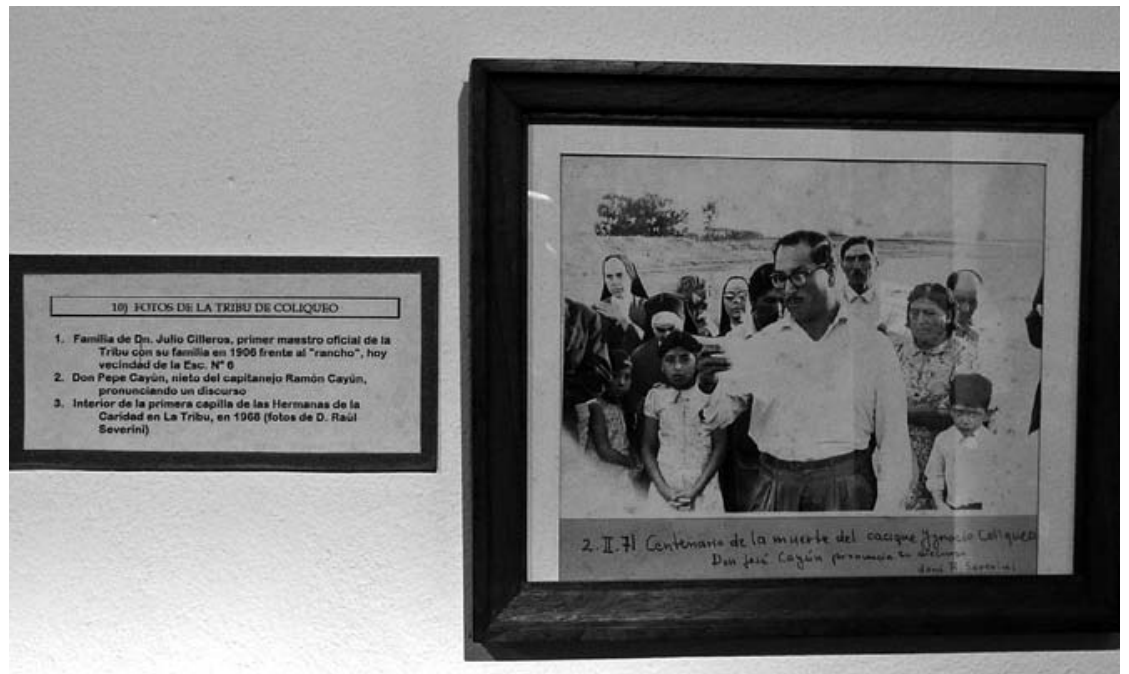

Fото 18. Museo del Indio de Los Toldos. Fotografía de la ceremonia conmemorativa de los cien años del fallecimiento del cacique Ignacio Coliqueo (1971). La figura principal es José Cayún, nieto del capitanejo Ramón Cayún. Foto: Jesús Bustamante, agosto de 2011. 
gistro de matrimonios de indios, año 1876», una carta autografiada dirigida por Ignacio Coliqueo al Juez de Paz y el boleto de compra de un solar en Los Toldos firmado por Antonio Coliqueo el 12 de agosto de 1895, así como una genealogía incompleta del «Grupo Familiar Coliqueo (Comunidad Mapuche de Los Toldos) ${ }^{35}$.

Otros objetos no identificados por su uso personal, como dos lanzas tacuaras de longitud excepcional (expuestas en un espacio breve destinado a recordar la Conquista del Desierto), textiles y joyas mapuches y una antiquísima máquina de escribir completan la exhibición. Curiosamente, la colección muestra también un cuadro de pobre factura representando a Caupolicán, el héroe de La Araucana de Ercilla, del que algunos miembros actuales de la familia Coliqueo dicen descender ${ }^{36}$.

Frente a este despliegue de la población indígena los otros dos contingentes - criollos e inmigrantes - tienen una presencia menor. Fotografías de familias de los primeros pobladores, una imagen del establecimiento «El Argentino» que Electo Urquizo fundó en el seno de la propia tribu de Coliqueo, un único vestido de novia, del color negro usual a finales del siglo XIX y con la característica de haber sido llevado por la maestra de primeras letras de Eva Perón, y una Virgen de Luján pintada en un asta de vaca son algunas de las piezas destacadas, más por su significación que por su valor intrínseco.

He clasificado a este museo de «historizante» porque la historia forma la columna vertebral de su discurso expositivo y de su recorrido, que transcurre a lo largo de un siglo y medio (con la excepción de la presencia apenas explicada de un mítico Caupolicán). No hay en él paleontología, y el indio aparece como el personaje histórico protagonista de un proceso en el tiempo cuyos hitos y personajes son bien conocidos. Las familias indígenas en particular, pero también las criollas e inmigrantes, están allí no para recordar a los abuelos fundadores, sino como expresión de la formación de un pueblo al que concurrieron los distintos contingentes poblacionales: quienes ya estaban (pero con fecha de ocupación bien definida), quien trabajó con ellos y acabó vinculando

34 Simón Coliqueo participó, junto con su padre y sus hermanos, en la batalla de Pavón (1861) que le dio el triunfo definitivo a Bartolomé Mitre sobre las armas de la Confederación. Por su actuación destacada, Simón fue considerado el Héroe de Pavón.

35 Aunque me he detenido especialmente en las fotografías y objetos de la familia Coliqueo por su condición de pobladores de la zona de Los Toldos, no faltan en esta exhibición fotografías de otros caciques renombrados del avance territorial y la Conquista del Desierto, como Pincén, Juan Catriel, Namuncurá, indios prisioneros de guerra, y el Capitanejo Villamaín en Peleg, Patagonia.

36 Esta interpretación no es compartida por el P. Hux. Conversación con el P. Meinrado Hux en agosto de 2011. 


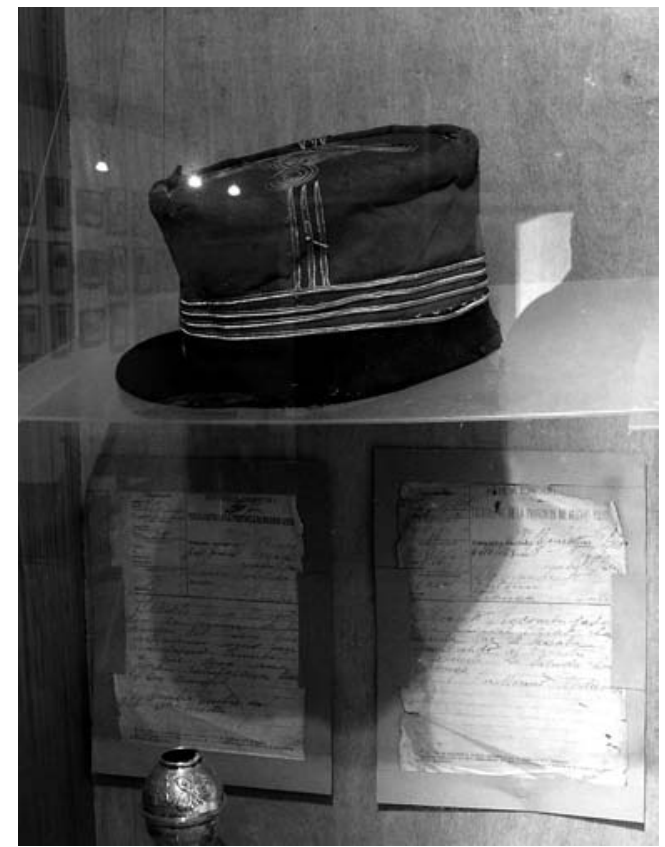

Fото 19. Museo Etnográfico y Archivo Histórico «Enrique Squirru» de Azul. Quepí del ejército argentino que perteneció al Sargento Mayor Simón Coliqueo. Foto: Jesús Bustamante, agosto de 2011.

sus tierras a la voluntad de crear una población, y quienes acudieron a ese llamado.

De tal forma, la ciudad de Los Toldos es el único caso de una población que, sin desconocer el hecho histórico de la Conquista del Desierto, no parte sin embargo de un espacio de colonización en el que el indio es el personaje hostil u hostilizado, sino de la colaboración y defensa mutua de una importante agrupación de indios amigos y un criollo muy especial, que vio en sus campos el germen de una ciudad futura. A lo que debe agregarse la actuación de un cronista que dedicó muchos años de su vida al estudio de la historia de las tribus indígenas de la pampa. En particular a la tribu de Ignacio Coliqueo, antecesor de una parte muy importante de la actual población de Los Toldos, ciudad donde se erige la Abadía de Santa María que aloja las instalaciones del Museo del Indio. Este conjunto de coincidencias está sin duda tras la erección de una institución museográfica que se ha alejado del indio vinculado a la fauna paleozoica, así como del «indio bárbaro» de la expansión poblacional que colonizó la provincia de Buenos Aires. En sus fotografías y en sus piezas, el 
museo despliega al «indio poblador» que fue también, como el criollo y el inmigrante, creador de asentamientos duraderos.

\section{CONCLUSIONES}

Al hacer el recorrido por los museos de la provincia de Buenos Aires nos hemos encontrado con una constante y distintos discursos expositivos. La constante es la presencia inevitable de una perspectiva que señala el origen de las respectivas poblaciones en un proceso de ocupación de espacios vinculado a la práctica de la violencia, que en el imaginario se asoció al enfrentamiento entre dos culturas disímiles y desniveladas. La colonización del espacio en ese contexto de violencia acerca a estos museos a las instituciones «coloniales» del mundo europeo, aunque con la característica ya señalada de que la población que a lo largo del siglo XIX era «otra», a finales de ese siglo se convirtió en «nosotros», fuera este último reconocido o no. Y en nuestros casos de estudio, el discurso colonial (de avance territorial, de sujeción de poblaciones ajenas) se entrelaza con el comunitario (de memorias de fundación y de fundadores).

Pero, además de esta constante, hay grandes diferencias entre los museos estudiados: no es lo mismo una institución destinada a mantener la memoria de la comunidad, que otra cuyo discurso expositivo se asocia al ámbito de los estudios científicos y a una perspectiva culturalista que responde a teorías antropológicas de duradera influencia, aunque hoy estén en parte superadas. Tampoco la voluntad comunitaria es igual en todos los casos: los hay que buscan mantener viva la memoria de los abuelos fundadores; otros ponen el acento en la expansión a lo largo del tiempo de un asentamiento de frontera convertido en ciudad. También hay diferencias entre museos que han cambiado recientemente su discurso expositivo - que suelen incorporar tendencias internacionales - y los que mantienen una estructura de muchas décadas, en los que la recepción de objetos entregados por la población constituye la base de la exhibición. Sin olvidar los museos de comunidad que están buscando una nueva identidad, más cercana a los descubrimientos científicos que se están expandiendo actualmente en las tierras pampeanas.

Ahora bien, si hay algo que vincula a estos museos con procesos hoy experimentados por las instituciones europeas coloniales, o bien etnográficas y antropológicas, es el principio del «miedo»: miedo a las tensiones socioétnicas, al enfrentamiento grupal, a perder piezas valiosas, a entrar en litigios que afecten no solo a los objetos sino a la propia convivencia. En este contexto, la voluntad estetizante que hemos visto desplegar en un museo con discurso recien- 
temente renovado se suma en otros casos a la identificación única del indio como figura arqueológica vinculada a la fauna paleozoica. Esto último sería legítimo y hasta lógico en un museo con fines universitarios o científicos con un objeto claramente delimitado, pero la presencia de la memoria de una población (criolla e inmigrante) con exclusión de otra (indígena) genera interrogantes sobre el museo como "gran lugar de la memoria, allí donde el discurso expositivo intenta expresar cómo una sociedad quiere ser vista, y cómo ve o quiere ver a las demás, en el presente y en su pasado» ${ }^{37}$.

Quisiera terminar este trabajo con dos comentarios. En primer lugar, en estos museos la visión evolucionista no suele responder a un principio de interpretación científica, sino más bien a un instrumento discursivo que facilita el orden de la exhibición: de más antiguo a más reciente. En este sentido no es muy distinto el tratamiento del tiempo en los museos que cruzan la paleoantropología con la paleozoología, del que puede apreciarse en una institución de carácter «historizante» que se centra en los procesos poblacionales de los dos últimos siglos. Finalmente, nuestra propuesta de una clasificación que no está incorporada en el planteamiento general de este volumen - los museos pot pourri, nombre con el que nos quisimos referir a la condición acusadamente miscelánea de algunas exhibiciones - no oculta que se trata en todos los casos de museos comunitarios; pero también lo son la mayoría de los restantes museos. Porque el principio de «comunidad» es demasiado amplio para diferenciar entre instituciones con tal abanico de voluntades expositivas. Lo cierto es que el carácter de museos que se erigen en localidades que fueran de frontera, con fechas de fundación muy recientes y una memoria histórica aún viva, plena de recuerdos que se mantienen en las poblaciones actuales aunque sea en sus estratos de mayor edad, presta a todos estos museos - sean «estetizantes», «historizantes» o, como hemos dicho antes, museos pot pourri; con la sola excepción quizá del «Dámaso Arce» de Olavarría, nuestro ejemplo de «museo culturalista» - una vocación indudable de memoria comunitaria.

\section{REFERENCIAS BIBLIOGRÁFICAS}

Estévez, Juan José, Historia trenquelauquenche, Trenque Lauquen AR, Trenque Lauquen, 1990.

Fernández, Stella Maris, Tierra de Quijotes. Ciudad Cervantina de la Argentina, Buenos Aires, Sociedad de Investigaciones Bibliotecnológicas, 2008.

37 Véase el trabajo de Jesús Bustamante en este mismo volumen. 
Hux, P. Meinrado, Caciques huiliches y salineros, Buenos Aires, Ediciones Marymar, $1991 \mathrm{a}$.

Hux, P. Meinrado, Caciques pehuenches, Buenos Aires, Ediciones Marymar, 1991b.

Hux, P. Meinrado, Caciques borogas y araucanos, Buenos Aires, Ediciones Marymar, 1992.

Hux, P. Meinrado, Memorias del ex cautivo Santiago Avendaño, Buenos Aires, El Elefante Blanco, 1999.

Hux, P. Meinrado, El Indio en las llanuras del Plata. Guía bibliográfica, Buenos Aires, Asociación Amigos de las Artes Tradicionales, 2 vols., 2000.

Hux, P. Meinrado, Caciques puelches, pampas y serranos, Buenos Aires, El Elefante Blanco, 2003.

Hux, P. Meinrado, Manuel Baigorria, Memorias, con prólogo, edición y notas de..., Buenos Aires, El Elefante Blanco, 2006.

Hux, P. Meinrado, Coliqueo, el indio amigo de Los Toldos, Buenos Aires, El Elefante Blanco, 2009.

Leonís Mazzanti, Diana, «La institucionalización de la arqueología desde Olavarría», Andes, 16 (Salta, enero-diciembre 2001) (versión on-line: ISSN 1668-8090).

Museo de Arte e Historia Municipal de Los Toldos, www.museolostoldos.com.ar/ meinrado_hux.htm

Museo de Arte e Historia Municipal de Los Toldos, www.museolostoldos.com.ar/ electo_urquizo.htm.

Museo Etnográfico y Archivo Histórico Enrique Squirru, Azul, Talleres Gráficos de Impresos San Cayetano, 2000.

Museo Roca, Instituto de Investigaciones Históricas (1986): La historia viva de Tapalqué. Fragmentos de textos documentales para la didáctica de la historia, Buenos Aires, 1986.

Quijada, Mónica (ed.), De los cacicazgos a la ciudadanía. Sistemas políticos en la frontera. Río de la Plata, siglos XVIII-XX, Berlín, Ibero-Amerikanisches Institut Preussischer Kulturbesitz, Gebr. Mann Verlag, 2011.

Renan, Ernest, ¿Qué es una nación? - Cartas a Strauss, Madrid, Alianza, 1987.

Urquizo, Electo, J., Los Toldos, mi Hijo [1914]. Estudio preliminar, revisación y ampliación del P. Meinrado Hux, Los Toldos, Imprenta Iparraguirre, 1992.

White, Richard, The Middle Ground. Indians, Empires and Republics in the Great Lakes Region, 1650-1815, Cambridge, Cambridge University Press, 1991. 


\section{Frontier Museums in the Province of Buenos Aires: between the glyptodon and the Indian settler}

During the 19th century the Argentinian province of Buenos Aires was a frontier ambit where the main society spread southward in waves, pushing out the indigenous populations and founding new cities. A part of the Indian groups remained on the "white» side of the porous frontier, in which many interactions and metissages took place. In the $20^{\text {th }}$ century the old frontier cities established museums aimed at guarding the memory of the community. These museums are the American counterpart of European "colonial» museums. This article studies the relationship of those museums with the groups that populated the land, especially the "friendly Indians» who were integrated within the frontier as population advanced. The museums studied, most of which are community museums, have been classified in four categories: pot pourri museums, «culturalist» museums, «aestheticizing» museums, and «historicizing» museums.

KEY WORDS: museums; frontier; frontier citizens; memory; community; friendly Indians; Indian settler. 